\title{
Mineral concentrations in herbage and soil in a Pinus radiata silvopastoral system in north-west Spain after sewage sludge and lime application
}

\author{
A. Rigueiro-Rodríguez*, M. R. Mosquera-Losada* and M. L. López-Díaz† \\ *Departamento de Producción Vegetal, University of Santiago de Compostela, Spain, and †Departamento de \\ Biología y Producción de los Vegetales, Centro Universitario de Plasencia, University of Extremadura Plasencia- \\ Cáceres, Spain
}

\begin{abstract}
Summary
Silvopastoral systems in north-west Spain can reduce the risk of fires and promote multi-purpose forest land use. Fertilizer application is important for optimal pasture and tree production. The application rate of sewage sludge as a fertilizer is regulated and is based on its nutrient concentration, especially nitrogen. The aim of this study was to assess the effect of three consecutive years of application of different application rates of sewage sludge and inorganic fertilizer, with or without lime $\left(2 \cdot 5 \mathrm{t} \mathrm{CaCO}_{3} \mathrm{ha}^{-1}\right)$ on the ammonium, nitrate and exchangeable $\mathrm{K}$, Ca and $\mathrm{Mg}$ contents in soil, and on the crude protein (CP), $\mathrm{K}, \mathrm{Ca}$ and $\mathrm{Mg}$ concentrations in herbage in a silvopastoral system established under a 5-year-old Pinus radiata D. Don plantation with a density of 1667 trees $\mathrm{ha}^{-1}$. The experiment was started in autumn 1997, when a pasture mixture was sown (25 kg ha ${ }^{-1}$ Lolium perenne, $10 \mathrm{~kg} \mathrm{ha}^{-1}$ Dactylis glomerata and $4 \mathrm{~kg} \mathrm{ha}^{-1}$ Trifolium repens). Changes in ammonium and nitrate content in the soil in response to liming and sewage sludge application reflected the initial $\mathrm{pH}$ of the soil. In general, liming increased the available $\mathrm{Ca}$ and $\mathrm{Mg}$ content in soil, and $\mathrm{CP}$ and $\mathrm{Ca}$ concentrations in herbage, but reduced exchangeable $\mathrm{K}$ content in the soil in the first year. Application of sewage sludge increased all of the measured nutrients in both soil and herbage.
\end{abstract}

Keywords: silvopastoralism, sewage sludge, herbage quality, soil nutrient concentrations

Correspondence to: M. R. Mosquera-Losada, EPS Lugo, University of Santiago de Compostela, Campus Universitario s/n, 27002 Lugo, Spain.

E-mail: romos@lugo.usc.es

Received 23 March 2006; revised 1 November 2006

\section{Introduction}

The establishment of silvopastoral systems on forest land in the region of Galicia in Spain would allow the production of livestock products from cattle, sheep, goats and horses in conjunction with wood products, and at the same time would reduce fire risk. Therefore, the implementation of systems of this type would help to solve two of the main problems affecting forestry in the region: low economic returns and high fire risk. Moreover, these systems improve forest access, which can facilitate silvicultural management procedures such as thinning and pruning (Mosquera-Losada et al., 2001c), while at the same time contributing to landscape value, and thereby helping rural tourism.

Galician forest soils are very acidic, with low production and nutritive value of herbage due to soil factors which include the high aluminium saturation of the exchange complex and low cation availability. Hence, it is expected that inputs of fertilizers with a high proportion of calcium (Ca) and magnesium $(\mathrm{Mg})$, such as sewage sludge and lime, will increase both the soil $\mathrm{pH}$ and the complex exchange capacity, reducing aluminium saturation of the exchange complex, and increasing organic matter (OM) mineralization (Bailey, 1995; Wheeler, 1998) thus increasing the availability of soil nitrogen (N) (Chambers and Garwood, 1998) and of phosphorus (P), Ca and Mg (Wheeler, 1998). Increased total nutrient availability normally results in increased herbage production and its nutritive value (Stevens and Laughlin, 1996). Applications of fertilizer to silvopastoral systems have been shown to increase both pasture and tree growth without harmful effects on trees (Sinclair et al., 2000). Fertilizer can be applied as inorganic and organic fertilizer but the effects of organic fertilizer on pasture production have been less extensively evaluated than the effects of inorganic fertilizer. There is little information on how sewage sludge inputs, and their interaction with liming, affect soil nutrient availability. 
Since the 1990s the implementation of the European Union (EU) Directive 91/271/CEE (European Commission, 1991) has led to a marked increase in sewage sludge production in EU countries. In 2005, estimated total annual sewage sludge production of dry matter (DM) in Europe was about $8.2 \times 10^{6} \mathrm{t}$ (Brodersen et al., 2002). Studies in several European countries on the use of sewage sludge as a fertilizer, which is regulated by EU Directive 86/278/CEE (European Commission, 1986), have concluded that sewage sludge is a good fertilizer due to its high content of macronutrients, particularly $\mathrm{N}$, and to a lesser extent of $\mathrm{P}, \mathrm{K}, \mathrm{Ca}$ and $\mathrm{Mg}$. However, the use of sewage sludge also has to take into account the higher proportion of heavy metals in the sludge than in the soil, as these are toxic elements that can enter the food chain constituting a health risk (Smith, 1996).

The effects of sewage sludge on pasture and tree growth in silvopastoral systems in north-west Spain have been evaluated (López-Díaz et al., 2005). In this study, the effects of different doses of sewage sludge and inorganic fertilizer, with or without lime $\left(2.5 \mathrm{t} \mathrm{CaCO}_{3} \mathrm{ha}^{-1}\right)$, on the ammonium, nitrate and exchangeable $\mathrm{K}, \mathrm{Ca}$ and $\mathrm{Mg}$ levels in soil, and on crude protein (CP), K, Ca and $\mathrm{Mg}$ concentrations in herbage in a pasture planted under a 5-year-old Pinus radiata plantation were investigated.

\section{Materials and methods}

\section{Characteristics of the study site}

The experiment was carried out in Lugo (NW Spain; $43^{\circ} 09^{\prime} \mathrm{N}$; $7^{\circ} 20^{\prime} \mathrm{W} ; 510 \mathrm{~m}$ a.s.l), over a period of 3 years. Mean monthly precipitation and temperatures for 1998 ,
1999 and 2000, and for the previous 20 years, are shown in Figure 1; total annual rainfall was 1083, 1291 and $1426 \mathrm{~mm}$ in 1998, 1999 and 2000 respectively. The experiment was carried out in a mountain area, on a sandy loam soil of about $50 \mathrm{~cm}$ in depth, strongly acid ( $\mathrm{pH}$ in water of 4.97$)$, and high in OM $\left(123.2 \mathrm{~g} \mathrm{~kg}^{-1}\right)$ and nitrogen $\left(5 \cdot 2 \mathrm{~g} \mathrm{~kg}^{-1}\right)$ content. Total nitrogen $(\mathrm{N})$ content was mainly in an organic form $(200.8 \mathrm{mg}$ $\left.\mathrm{N}-\mathrm{NH}_{4}{ }^{+} \mathrm{kg}^{-1} ; 4 \cdot 4 \mathrm{mg} \mathrm{N}-\mathrm{NO}_{3}^{-} \mathrm{kg}^{-1}\right)$. Total P content was very low $\left(0.3 \mathrm{~g} \mathrm{~kg}^{-1}\right)$, as is usual in this area. Aluminium saturation in the exchange complex (Al/IC) was very high $(55.15 \%)$, indicating possible toxicity problems, low $\mathrm{P}$ and $\mathrm{N}$ availability, and low availability of exchangeable bases [K: $0 \cdot 13 \mathrm{cmol}(+) \mathrm{kg}^{-1}$; Ca: $1.35 \mathrm{cmol}(+) \mathrm{kg}^{-1} ; \quad \mathrm{Mg}: \quad 0.41 \mathrm{cmol}(+) \mathrm{kg}^{-1} ; \quad \mathrm{Na}$ : $\left.0 \cdot 49 \mathrm{cmol}(+) \mathrm{kg}^{-1}\right]$. All heavy metal concentrations in the soil were below the maximum thresholds for using sewage sludge as fertilizer, as specified by the European Union Directive 86/278/CEE (European Commission, 1986), and Spanish legislation under R.D. 1310/1990 (BOE, 1990).

\section{Experimental design}

The experimental design was a completely randomized block with three replicates. The experiment was established under a 5-year-old $P$. radiata (Monterrey pine) plantation, with a density of 1667 trees ha ${ }^{-1}$. Plots (perfect squares of 5 trees $\times 5$ trees with an area of $96 \mathrm{~m}^{2}$ ) were sown with a mixture of $25 \mathrm{~kg} \mathrm{ha}^{-1}$ of Lolium perenne cv. Brigantia (perennial ryegrass), $10 \mathrm{~kg} \mathrm{ha}^{-1}$ of Dactylis glomerata cv. Artabro (cocksfoot) and $4 \mathrm{~kg} \mathrm{ha}^{-1}$ of Trifolium repens cv. Huia (white clover) after scrub clearance and ploughing in autumn 1997. The soil was initially fertilized with $120 \mathrm{~kg} \mathrm{P}_{2} \mathrm{O}_{5} \mathrm{ha}^{-1}$ and
Figure I Monthly precipitation and mean temperature for the study area in 1998, 1999 and 2000, and mean data for the last 20 years. $T(-)$ : temperature in 1998, 1999 and 2000; Tm (-.-.): mean temperature over the last 20 years; $\mathrm{P}(---)$ : precipitation in 1998, 1999 and 2000; Pm (...): mean precipitation over the last 20 years.

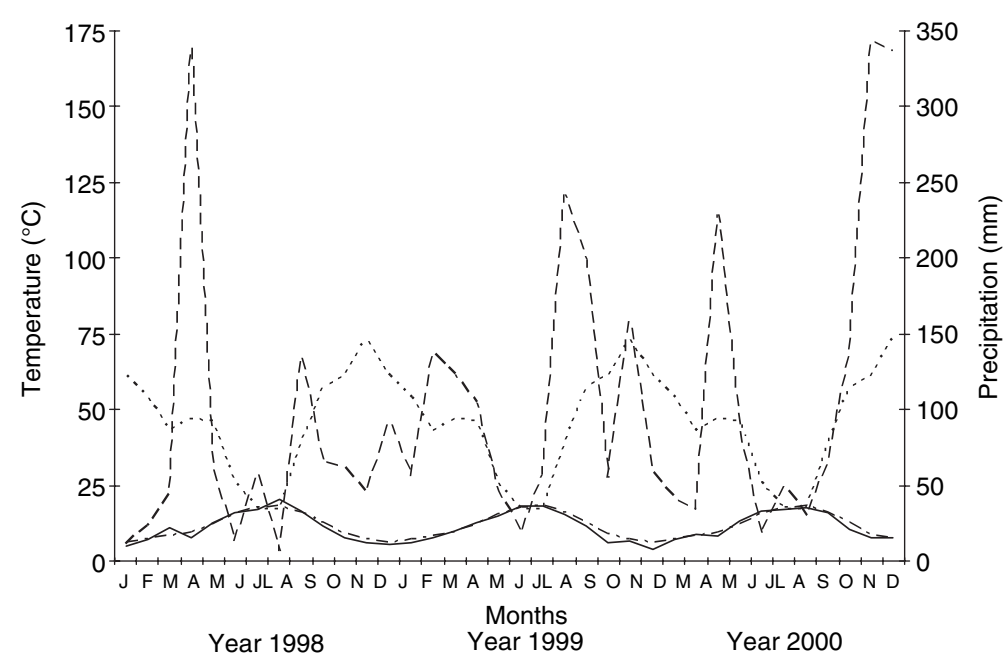


$200 \mathrm{~kg} \mathrm{~K}_{2} \mathrm{O} \mathrm{ha}^{-1}$, consistent with conventional pasture fertilizer practice for autumn pasture establishment in the region. Treatments were no fertilizer application (NF), and three rates of sewage sludge application based on analysis of its $\mathrm{N}$ content. These were $\mathrm{Ll}: 160 \mathrm{~kg}$ total $\mathrm{N} \mathrm{ha}^{-1}$; $\mathrm{L} 2: 320 \mathrm{~kg}$ total $\mathrm{N} \mathrm{ha}^{-1}$; L3: $480 \mathrm{~kg}$ total $\mathrm{N}$ $\mathrm{ha}^{-1}$, with or without liming $\left(2 \cdot 5 \mathrm{t} \mathrm{CaCO}_{3} \mathrm{ha}^{-1}\right)$ in each case. A control treatment with mineral fertilization (MIN) without liming was also included in the comparison. This consisted of the application of $500 \mathrm{~kg} \mathrm{ha}^{-1}$ of $\mathrm{N}, \quad \mathrm{P}_{2} \mathrm{O}_{5}$ and $\mathrm{K}_{2} \mathrm{O}$ fertilizer (8:24:16) supplying $40 \mathrm{~kg} \mathrm{~N} \mathrm{ha}^{-1}, 120 \mathrm{~kg} \mathrm{P}_{2} \mathrm{O}_{5} \mathrm{ha}^{-1}$ and $80 \mathrm{~kg} \mathrm{~K}_{2} \mathrm{O} \mathrm{ha}^{-1}$ at the start of the growing season in 1998, 1999 and 2000. There were thus nine treatments in total. Sewage sludge doses were based on total $\mathrm{N}$ and mineral $\mathrm{N}$ concentrations in line with Environment Protection Agency (EPA) recommendations (EPA, 1994), which assumes that around $0 \cdot 25$ of total nitrogen applied with anaerobicdigested sewage sludge will be mineralized in the first year. Lime was applied just before sowing.

\section{Sewage sludge}

Anaerobically digested municipal sewage sludge was produced in Lugo. Heavy metal concentrations were below the Spanish legally permitted limits for use in agriculture (BOE, 1990). The composition of sewage sludge batches used in 1998, 1999 and 2000 are shown in Table 1 indicating a high-quality product. It had a low content of heavy metals (data not presented).

\section{Herbage samples}

Plots were harvested eight times during the experiment, in July and December in 1998, and May, July and November in 1999 and 2000. Before harvesting, four herbage samples (each of $0.09 \mathrm{~m}^{2}$ ) were taken from each plot using hand clippers at a height of $2.5 \mathrm{~cm}$. At the same time, soil samples from 0 to $5.5 \mathrm{~cm}$ horizon were taken from randomly selected locations within each plot.

\section{Analyses}

Soil samples were dried at $40^{\circ} \mathrm{C}$, passed through a 2-mm sieve and ground with an agate mortar. Ammo- nium $\left(\mathrm{N}-\mathrm{NH}_{4}^{+}\right)$and nitrate $\left(\mathrm{N}-\mathrm{NO}_{3}^{-}\right)$concentrations were evaluated after extraction with $0 \cdot 2 \mathrm{M} \mathrm{KCl}$ (Bremner, 1965). Exchangeable cations were evaluated after extraction with $0.6 \mathrm{~N} \mathrm{BaCl}_{2}$ (Guitián and Carballas, 1976) with a VARIAN 220FS spectrophotometer, using atomic emission spectrophotometry for exchangeable K and absorption spectrophotometry for exchangeable Ca and $\mathrm{Mg}$ (Varian, 1989).

Herbage samples were dried in an oven at $80^{\circ} \mathrm{C}$ for $48 \mathrm{~h}$. Concentrations of $\mathrm{CP}, \mathrm{P}, \mathrm{Ca}, \mathrm{K}$ and $\mathrm{Mg}$ were determined after micro-kjeldahl digestion (Castro et al., 1990). Nitrogen concentration was evaluated by colorimetry with an autoanalyser as described by Castro et al. (1990). Crude protein concentration was estimated by multiplying $\mathrm{N}$ concentration by 6.25 (Whitehead, 1995). Concentrations of K, Ca and Mg were measured with a VARIAN 220FS spectrophotometer using atomic emission for $\mathrm{K}$ and absorption for $\mathrm{Ca}$ and $\mathrm{Mg}$ (Varian, 1989).

\section{Statistical analysis}

Data were analysed as randomized block design with sewage sludge treatments, liming treatments and sampling dates as the main factors by Anova with Duncan tests for pairwise comparison of means. All analyses were performed with the SAS package (SAS, 2001).

\section{Results}

\section{Mineral concentrations in soil}

Ammonium $\left(\mathrm{N}-\mathrm{NH}_{4}^{+}\right)$and nitrate $\left(\mathrm{N}-\mathrm{NO}_{3}^{-}\right)$contents in soil were significantly affected by the fertilizer treatments in all 3 years. At the moderate and high sludge applications (L2 and L3), liming did not affect ammonium content in the soil (Figure 2), but increased nitrate content in the soil in spring 1999 (Figure 3). Increasing sewage sludge application rates generally raised ammonium and nitrate contents in the soil (Figure 3). In 1999 and 2000, ammonium content was proportional to applied sewage sludge $\left(\mathrm{N}-\mathrm{NH}_{4}^{+}=54 \cdot 97 * \mathrm{~N}+82 \cdot 16\right.$, $r^{2}=0.94$ and $\mathrm{N}-\mathrm{NH}_{4}^{+}=42.73 * \mathrm{~N}+41 \cdot 43, r^{2}=0.93$, respectively), as well as nitrate content in November $1999\left(\mathrm{~N}-\mathrm{NO}_{3}^{-}=6 \cdot 89 * \mathrm{~N}+6 \cdot 46, r^{2}=0 \cdot 94\right)$. The incre-

Table I Basic properties of the sewage sludge batches used in 1998, 1999 and 2000, showing dry matter content (DM, g kg-1), pH in water, organic matter concentration (OM conc., $\mathrm{g} \mathrm{kg}^{-1}$ ), carbon:nitrogen (C:N) ratio and $\mathrm{N}, \mathrm{P}, \mathrm{K}, \mathrm{Ca}, \mathrm{Mg}$ and $\mathrm{Na}$ concentrations (conc.; $\mathrm{g} \mathrm{kg}^{-1}$ ).

\begin{tabular}{|c|c|c|c|c|c|c|c|c|c|c|}
\hline Year & DM content & pH & OM conc. & $\mathrm{C}: \mathbf{N}$ ratio & N conc. & P conc. & K conc. & Ca conc. & Mg conc. & Na conc. \\
\hline 1998 & 250 & $6 \cdot 94$ & 490 & 8.85 & $32 \cdot 1$ & $9 \cdot 3$ & $2 \cdot 5$ & $6 \cdot 7$ & $5 \cdot 4$ & 0.8 \\
\hline 1999 & 250 & $6 \cdot 94$ & 393 & $7 \cdot 09$ & $32 \cdot 1$ & $5 \cdot 2$ & 2.5 & 6.9 & $4 \cdot 3$ & $0 \cdot 2$ \\
\hline 2000 & 235 & 6.94 & 441 & 6.05 & $43 \cdot 2$ & $16 \cdot 5$ & $2 \cdot 6$ & 6.5 & 6.5 & $1 \cdot 4$ \\
\hline
\end{tabular}



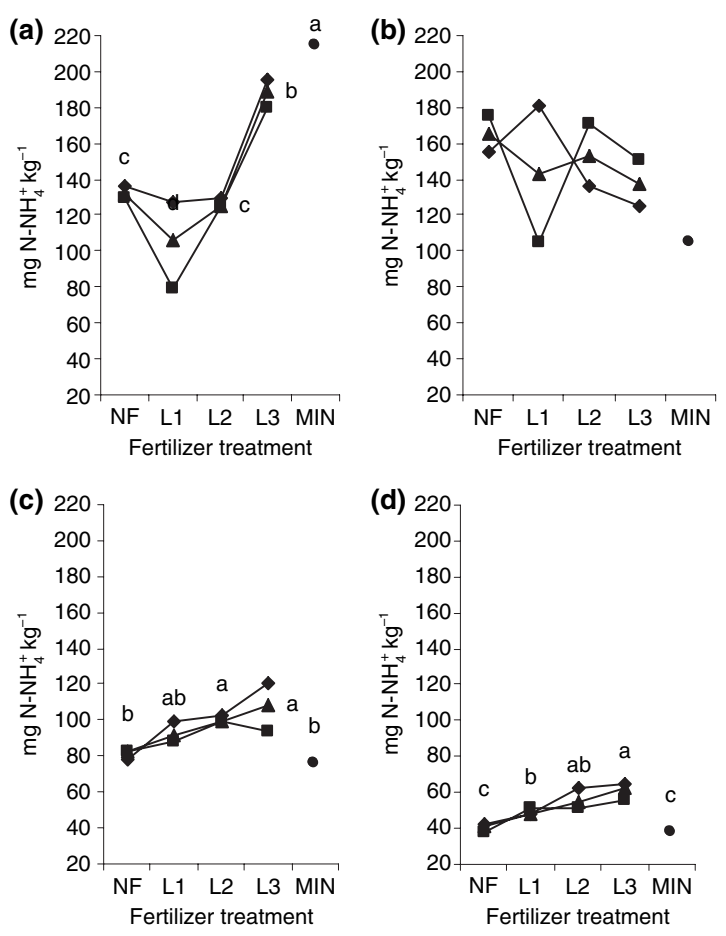

Figure 2 Mean ammonium contents ( $\mathrm{mg} \mathrm{N}-\mathrm{NH}_{4}^{+} \mathrm{kg}^{-1}$ ) in soil under the different liming and fertilizer treatments in (a) July 1998, (b) December 1998, (c) 1999 and (d) 2000. Liming

application rate was $2.5 \mathrm{t} \mathrm{CO}_{3} \mathrm{Ca} \mathrm{ha}^{-1}$; NF, no-fertilizer treatment; LI: low sewage sludge application rate $(160 \mathrm{~kg}$ total $\left.\mathrm{N} \mathrm{ha}^{-1}\right)$; L2, medium sewage sludge application rate (320 kg total $\mathrm{N} \mathrm{ha}^{-1}$ ); L3, high sewage sludge application rate (480 kg total $\mathrm{N} \mathrm{ha}^{-1}$ ); MIN, mineral fertilizer treatment. Different letters indicate significantly differences between fertilization treatments for each liming doses ( $\bullet$, no lime; lime) or the mean of both $(\boldsymbol{\Delta})(P<0.05)$. Means with the same letter do not differ significantly at $P=0.05$.

ment was more marked in the $\mathrm{L} 3$ treatment in the first year, and in the treatments L2 and L 3 in the first harvest of the second and third years. In general, the mineral (MIN) and no-fertilization (NF) treatments had no significant effects on ammonium and nitrate contents in soil.

Throughout the experiment, both liming and sewage sludge applications significantly increased exchangeable Ca content (Figure 4), with the increase induced by sewage sludge being more marked in the second year. Specifically, mean exchangeable Ca content in the soil of the sludge-fertilized plots in May, July and November 2000 were $4 \cdot 84-8 \cdot 14,4 \cdot 45-5 \cdot 77$ and $5 \cdot 23-$ $10 \cdot 15 \mathrm{cmol}(+) \mathrm{kg}^{-1}$. In most cases, this was significantly higher than in the no-fertilizer plots, which had values of $3.18,1.99$ and $2.77 \mathrm{cmol}(+) \mathrm{kg}^{-1}$ respectively. This effect of sewage sludge was mainly due to effects in the limed plots (Figure 4). In 2000, in the first (May) and the last (November) samples, Ca concentration in the exchange complex was proportional to sewage sludge application rate, as shown in the equations $(\mathrm{Ca}=$ $10 \cdot 34 \mathrm{~N}+3 \cdot 18, r^{2}=0.97$ and $\mathrm{Ca}=15 \cdot 36 \mathrm{~N}+2 \cdot 78, r^{2}=$ $0 \cdot 96$, respectively). In contrast, there was no effect of mineral fertilization.

$\mathrm{K}$ extracted by $\mathrm{BaCl}_{2}$ was significantly reduced after the liming application in July 1998, from 0.12 to $0.06 \mathrm{cmol}(+) \mathrm{kg}^{-1}$, and in most cases was also reduced by liming in 2000 (Figure 5). In 2000, the response in exchangeable $\mathrm{K}$ content to sewage sludge fertilizer treatments depended significantly on previous lime application. As was the case with exchangeable Ca content, the effect of sewage sludge on responses in exchangeable K content was delayed with respect to the effect of liming. In autumn 1999, exchangeable K content decreased in the sewage sludge-treated plots $\left(0 \cdot 07-0 \cdot 11 \mathrm{cmol}(+) \mathrm{kg}^{-1}\right)$ compared with unfertilized plots $\left[0 \cdot 18 \mathrm{cmol}(+) \mathrm{kg}^{-1}\right]$. However, in 2000, sewage sludge application increased exchangeable $\mathrm{K}$ content, particularly on the unlimed treatments. In May 2000, exchangeable $\mathrm{K}$ content in non-limed plots was proportional to sewage sludge application rate, as shown by the regression equation $(K=6 \cdot 34 \mathrm{~N}+1 \cdot 26$, $\left.r^{2}=0 \cdot 88\right)$. In July 2000, exchangeable $K$ content in the soil was positively affected by increased sewage sludge application rate, reaching $0 \cdot 28 \mathrm{cmol}(+) \mathrm{kg}^{-1}$ at the highest rate. When liming had been applied previously, the positive response to sewage sludge application was observed at the lowest rate, but a negative response was observed at the medium and highest rates. A similar response was seen in the final sampling of 2000.

During the first 2 years, mineral fertilizer had no effect on exchangeable K content. At the end of 1999, exchangeable $\mathrm{K}$ content was higher after mineral fertilizer application $\left[0 \cdot 15 \mathrm{cmol}(+) \mathrm{kg}^{-1}\right]$ than in the sludgefertilized plots $\left[0 \cdot 07-0 \cdot 12 \mathrm{cmol}(+) \mathrm{kg}^{-1}\right]$, though similar to the no-fertilizer plots $\left[0 \cdot 17-0 \cdot 18 \mathrm{cmol}(+) \mathrm{kg}^{-1}\right]$. However, from July 2000 onwards, mineral fertilizer application increased exchangeable $\mathrm{K}$ contents in soil with respect to the NF treatment (Figure 5).

Liming and sewage sludge application treatments significantly increased $\mathrm{Mg}$ availability from 1999 onwards and 1998 onwards respectively (Figure 6). These responses were mainly seen at the medium and high sewage sludge application rates, although in some harvests also at the lowest rate. The degree of the increase in some harvests was proportional to the sewage sludge application rates, as indicated by the regression equations $\left(\mathrm{Mg}=0 \cdot 68 \mathrm{~N}+0 \cdot 25, r^{2}=0 \cdot 87\right.$ in May 1999 and $\mathrm{Mg}=0 \cdot 66 \mathrm{~N}+0 \cdot 22, r^{2}=0 \cdot 87$ in July 1999). In general, exchangeable $\mathrm{Mg}$ concentrations in mineral-fertilized plots were similar or lower than those in NF plots and lower than those in sewage sludgefertilized plots. 
(a)

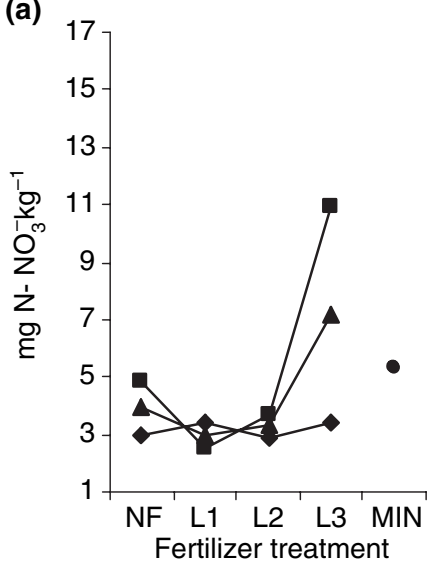

(d)

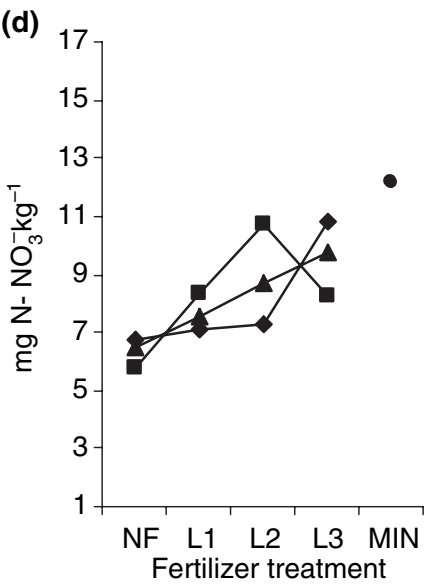

(b)

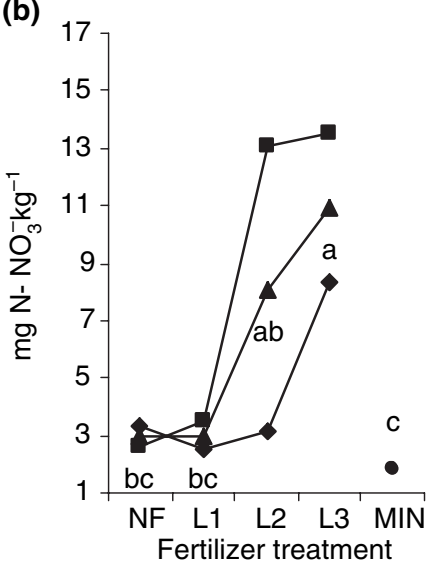

(e)

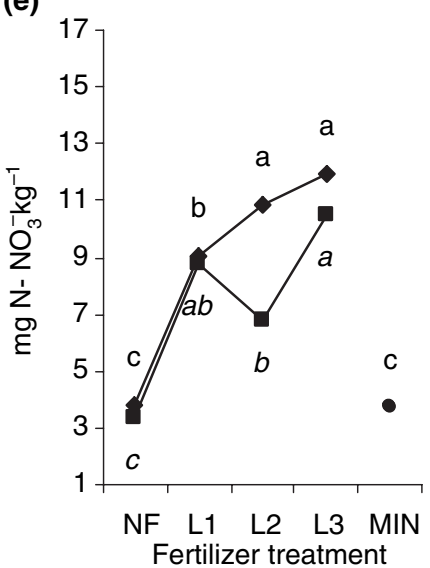

(c)

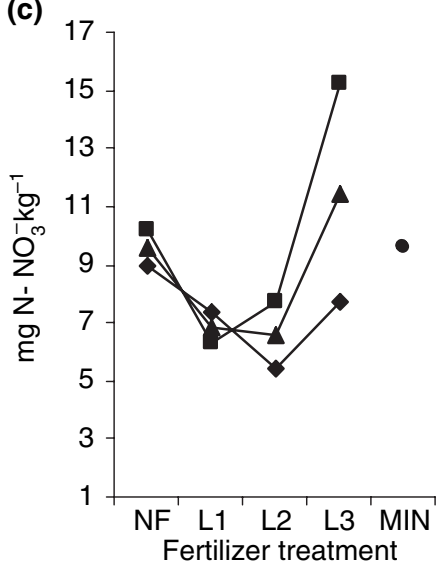

(f)

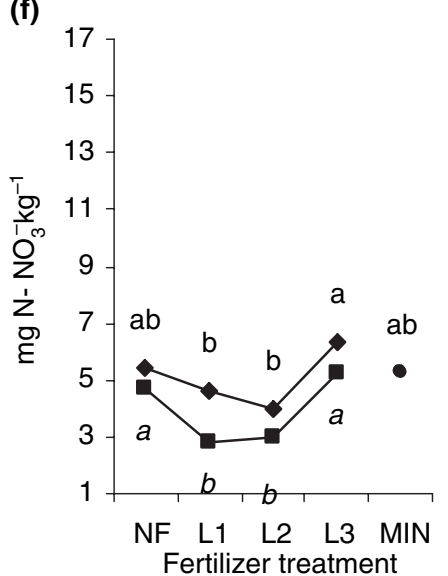

(g)

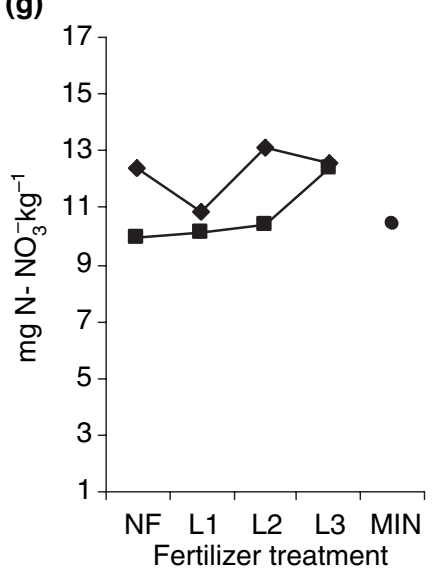

Figure 3 Mean nitrate contents ( $\mathrm{mg} \mathrm{N}-\mathrm{NO}_{3}^{-} \mathrm{kg}^{-1}$ ) in soil under the different liming and fertilizer treatments in (a) 1998, (b) May 1999, (c) July 1999, (d) November 1999, (e) May 2000, (f) July 2000 and (g) November 2000. Liming application rate was $2.5 \mathrm{t} \mathrm{CO}_{3} \mathrm{Ca} \mathrm{ha}^{-1}$; NF, no-fertilizer treatment; LI, low sewage sludge application rate (160 kg total N ha ${ }^{-1}$ ); L2, medium sewage sludge application rate $\left(320 \mathrm{~kg}\right.$ total $\left.\mathrm{N} \mathrm{ha}^{-1}\right) ; \mathrm{L} 3$, high sewage sludge application rate (480 $\mathrm{kg}$ total $\left.\mathrm{N} \mathrm{ha}^{-1}\right) ; \mathrm{MIN}$, mineral fertilizer treatment. Different letters indicate significantly differences between fertilization treatments for each liming doses $(\bullet$, no lime; lime) or the mean of both $(\mathbf{\Lambda})(P<0.05)$. 
(a)

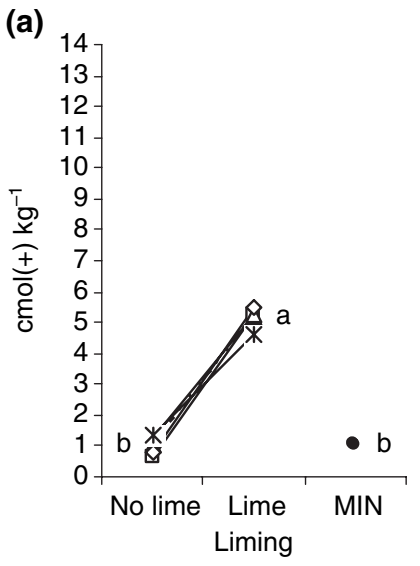

(d)

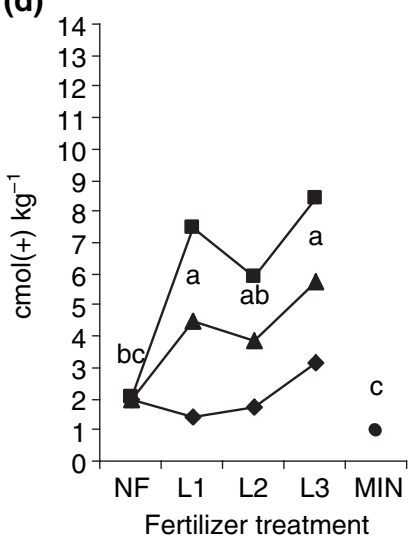

(b)

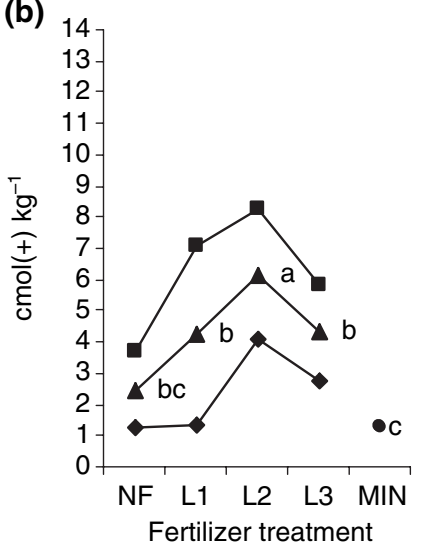

(e)

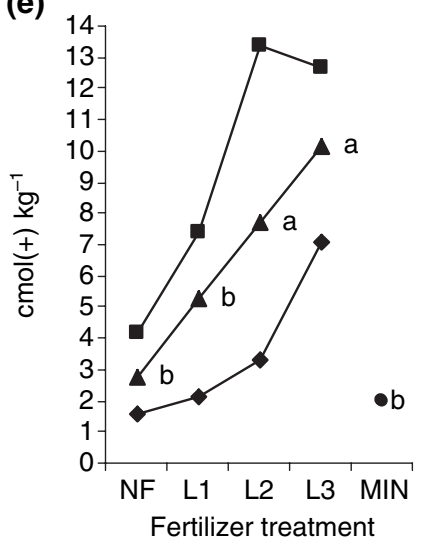

(c) 14

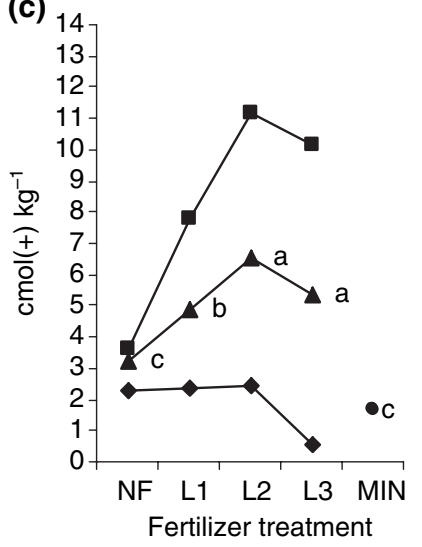

Figure 4 Mean exchangeable Ca contents $\left[\mathrm{cmol}^{(+)} \mathrm{kg}^{-1}\right]$ in soil under the different liming and fertilizer treatments in (a) 1998, (b) 1999, (c) May 2000, (d) July 2000 and (e) November 2000. Liming application rate was $2 \cdot 5 \mathrm{t} \mathrm{CO}_{3} \mathrm{Ca}_{\mathrm{a}} \mathrm{ha}^{-1}$; NF, no-fertilizer treatment; LI, low sewage sludge application rate ( $60 \mathrm{~kg}$ total $\left.\mathrm{N} \mathrm{ha}^{-1}\right)$; L2, medium sewage sludge application rate (320 kg total $\left.\mathrm{N} \mathrm{ha}^{-1}\right)$; L3, high sewage sludge application rate (480 $\mathrm{kg}$ total $\left.\mathrm{N} \mathrm{ha}^{-1}\right) ; \mathrm{MIN}$, mineral fertilizer treatment. Different letters indicate significantly differences between liming $\left(-\mathbf{\Lambda}^{-}\right)$or fertilizer treatments $(\mathbf{\Lambda})(P<0.05)$.

\section{Mineral concentrations in herbage}

In all 3 years, the maximum $\mathrm{CP}$ concentration was reached in the spring. Liming increased significantly the CP concentration in herbage in 1998 and sewage sludge application significantly increased CP concentration in herbage throughout the experiment (Figure 7). From 1999 onwards, the response to sewage application depended on the harvest period. The positive response to sewage sludge application was proportional to the rate applied, as was noticed with the mineral fertilizer, in July $1998\left(\mathrm{CP}=12 \cdot 45 \mathrm{~N}+8 \cdot 65, r^{2}=0 \cdot 83\right)$, December $1998\left(\mathrm{CP}=12 \cdot 45 \mathrm{~N}+8 \cdot 65, r^{2}=0 \cdot 83\right)$, May 1999 $\left(\mathrm{CP}=14.55 \mathrm{~N}+11.66, r^{2}=0.87\right)$, July $1999(\mathrm{CP}=$ $\left.4 \cdot 24 \mathrm{~N}+11 \cdot 63, r^{2}=0 \cdot 85\right)$, May $2000(\mathrm{CP}=19 \cdot 93 \mathrm{~N}+$ $8.45, r^{2}=0.96$ in non-limed plots and $\mathrm{CP}=14.30 \mathrm{~N}+$ $11 \cdot 31, r^{2}=0.82$ in limed plots) and July 2000 in limed plots $\left(\mathrm{CP}=22 \cdot 17 \mathrm{~N}+8 \cdot 69, r^{2}=0 \cdot 95\right)$.
Liming significantly increased the Ca concentration in herbage in 1998 and the autumn of 2000 (Figure 8). Ca concentration in herbage was only significantly increased by sewage sludge from the end of 1999 to the beginning of 2000. In July and November 1999, the response in $\mathrm{Ca}$ concentration in pasture was proportional to nitrogen applied with sewage sludge in July $\left(\mathrm{Ca}=-1.81 \mathrm{~N}^{2}+0.99 \mathrm{~N}+0.33, r^{2}=0.90\right)$ and November $1999\left(\mathrm{Ca}=-2 \cdot 93 \mathrm{~N}^{2}+1 \cdot 93 \mathrm{~N}+0 \cdot 25, r^{2}=0 \cdot 99\right)$. In the last year of the experiment (2000), the response in Ca concentration in herbage depended significantly on whether or not lime had been applied previously. In general, mineral fertilizer application had no significant effects on Ca concentrations in herbage.

No clear seasonal variations in $\mathrm{K}$ concentration in herbage were observed in 1998 and 2000 (Figure 9). In 1999, there was an increase in $\mathrm{K}$ concentration in herbage in the spring after treatments had been applied, 
(a)

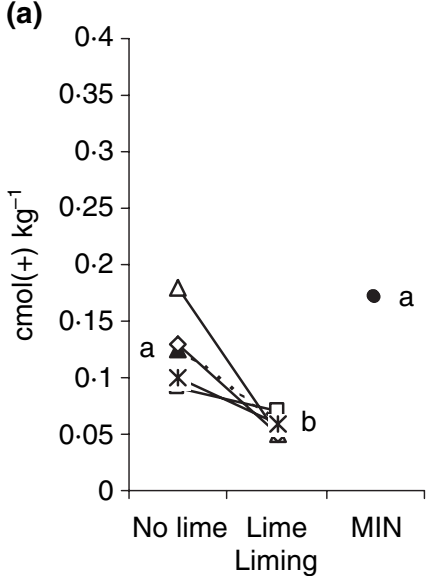

(d)

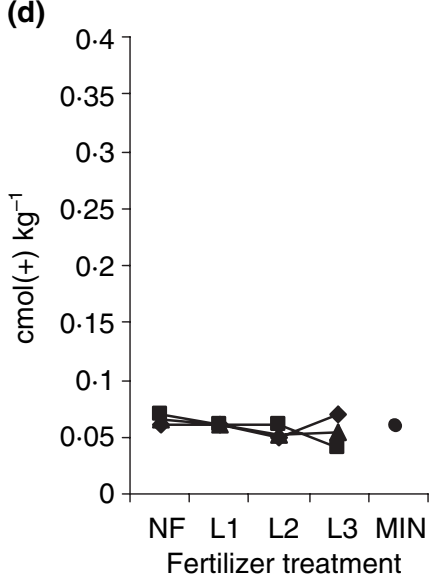

(g)

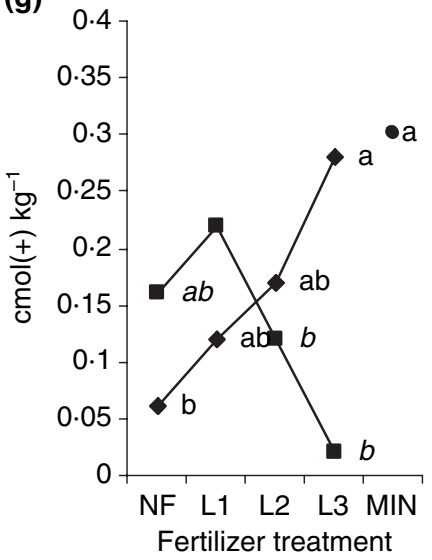

(b)

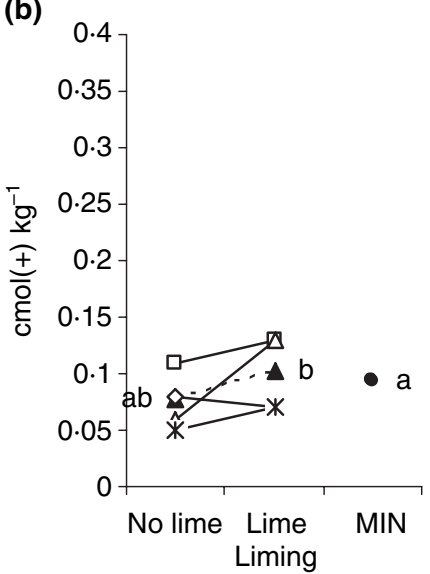

(e)

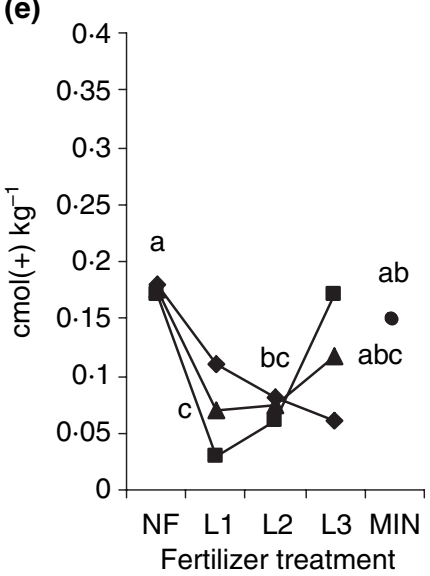

(h)

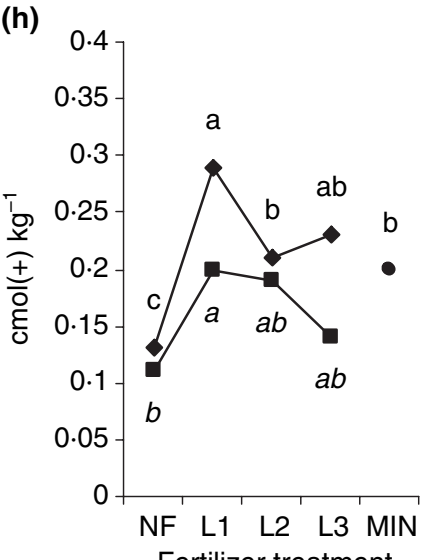

(c)

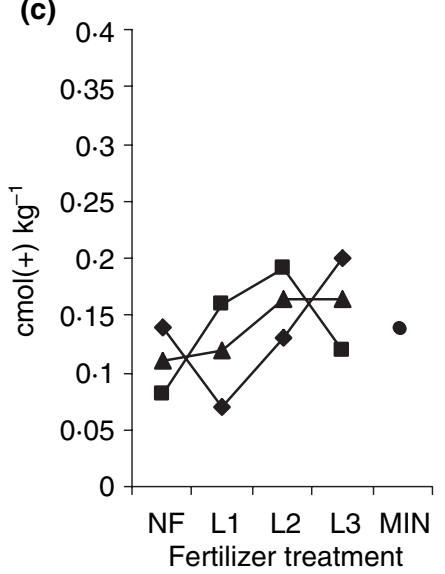

(f)

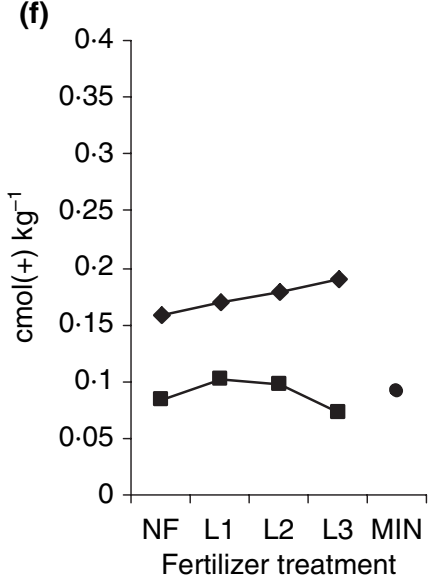

Figure 5 Mean exchangeable $\mathrm{K}$ contents $\left[\mathrm{cmol}(+) \mathrm{kg}^{-1}\right]$ in soil under the different liming and fertilizer treatments in (a) July 1998, (b) December 1998, (c) May 1999, (d) July 1999, (e) December 1999, (f) May 2000, (g) July 2000 and (h) December 2000. Liming application rate was $2.5 \mathrm{t} \mathrm{CO}_{3} \mathrm{Ca} \mathrm{ha}^{-1}$; NF, no-fertilizer treatment; LI, low sewage sludge application rate ( $60 \mathrm{~kg}$ total $\mathrm{N} \mathrm{ha}^{-1}$ ); L2, medium sewage sludge application rate (320 $\mathrm{kg}$ total $\left.\mathrm{N} \mathrm{ha}^{-1}\right)$; L3, high sewage sludge application rate $\left(480 \mathrm{~kg}\right.$ total $\left.\mathrm{N} \mathrm{ha}^{-1}\right)$; MIN, mineral fertilizer treatment different letters indicate significantly differences between liming $(-\boldsymbol{\Lambda}-)$, fertilization treatments ( $\bullet$, no lime; $\mathbf{\square}$, lime) or the mean of both $(\mathbf{\Lambda})(P<0$.05). 

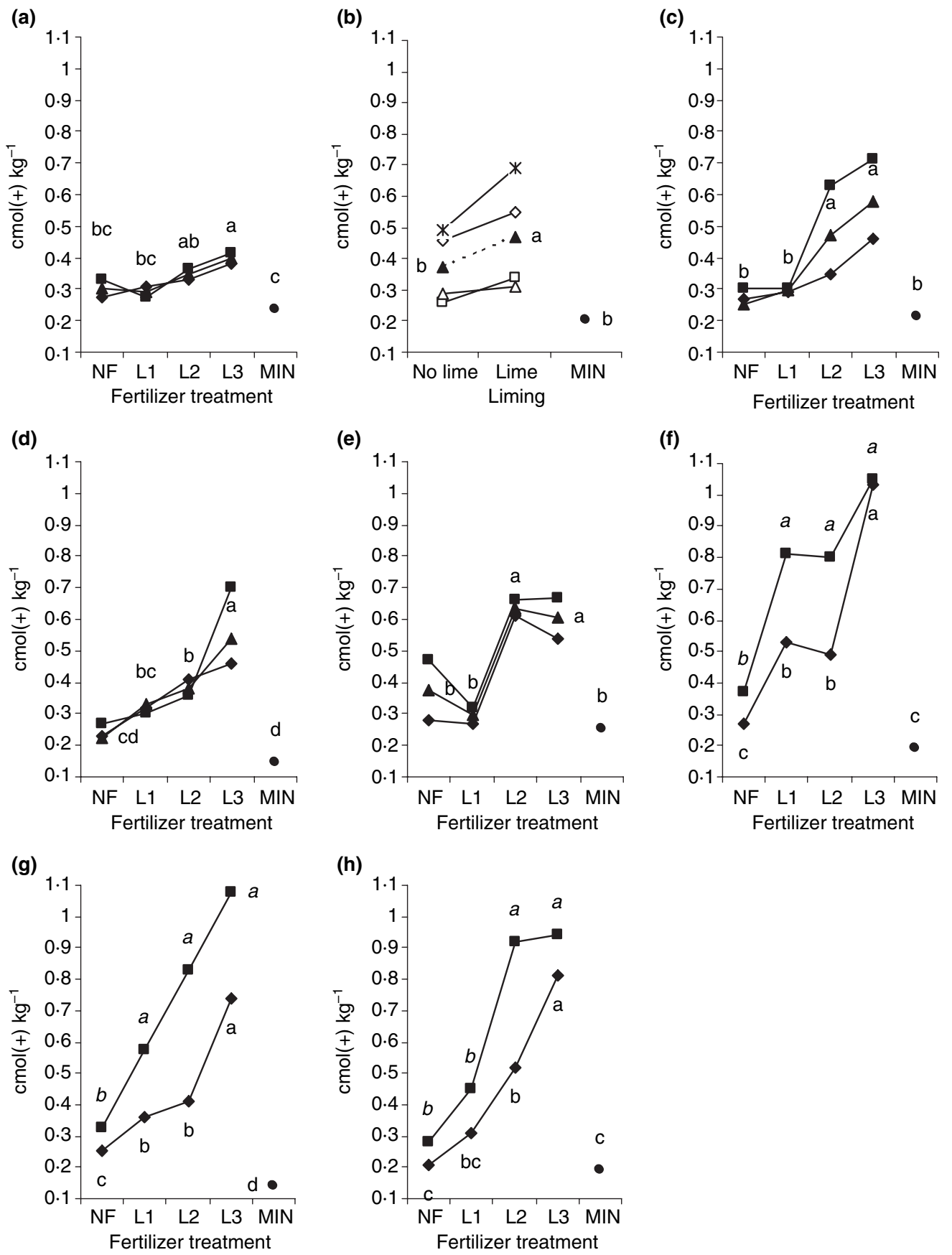

Figure 6 Mean exchangeable $\mathrm{Mg}$ concentrations $\left[\mathrm{cmol}^{(+)} \mathrm{kg}^{-1}\right]$ in soil under the different liming and fertilizer treatments in (a) 1998, (b) 1999, (c) May 1999, (d) July 1999, (e) November 1999, (f) May 2000, (g) July 2000 and (h) December 2000. Liming application rate was $2.5 \mathrm{t} \mathrm{CO}_{3} \mathrm{Ca} \mathrm{ha}{ }^{-1}$; NF, no-fertilizer treatment; LI, low sewage sludge application rate ( $60 \mathrm{~kg}$ total N ha $\left.{ }^{-1}\right)$; L2, medium sewage sludge application rate $\left(320 \mathrm{~kg}\right.$ total $\left.\mathrm{N} \mathrm{ha}^{-1}\right) ; \mathrm{L} 3$, high sewage sludge application rate (480 $\mathrm{kg}$ total $\mathrm{N}$ ha ${ }^{-1}$ ); $\mathrm{MIN}$ mineral fertilizer treatment. Different letters indicate significantly differences between liming $(-\boldsymbol{\Lambda}-)$, fertilization treatments $(\boldsymbol{\bullet}$, no lime; $\mathbf{\square}$, lime) or the mean of both $(\mathbf{\Lambda})(P<0.05)$. 
(a)

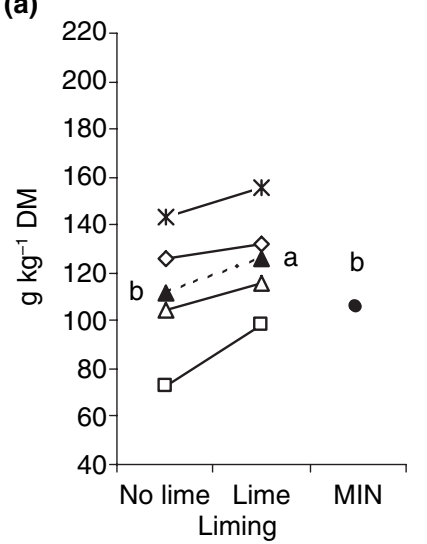

(d)

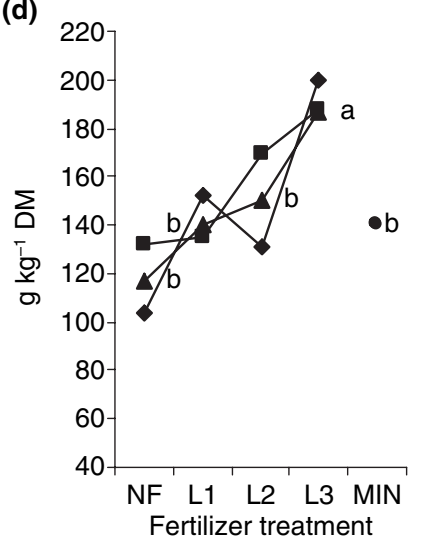

(g)

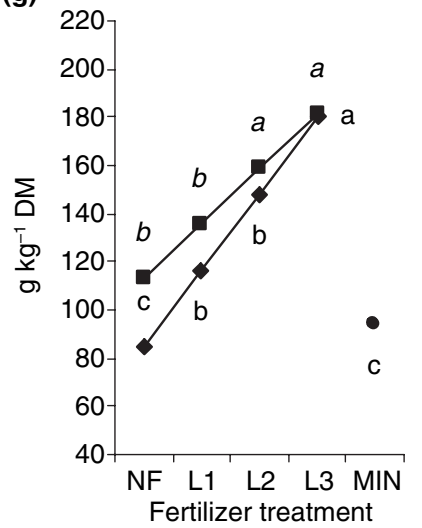

(b)

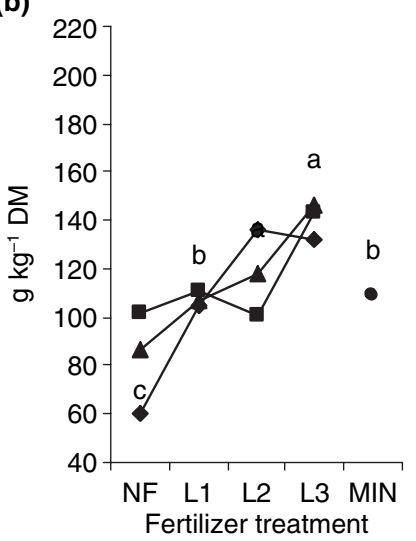

(e)

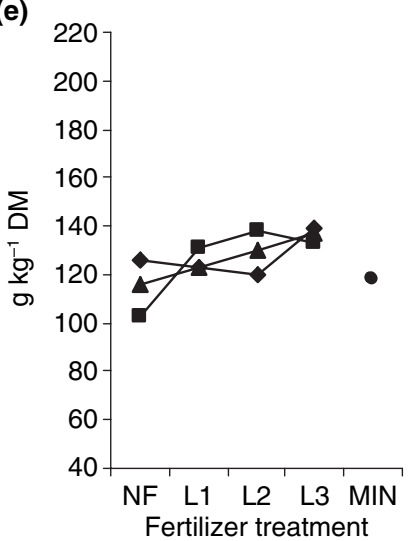

(h)

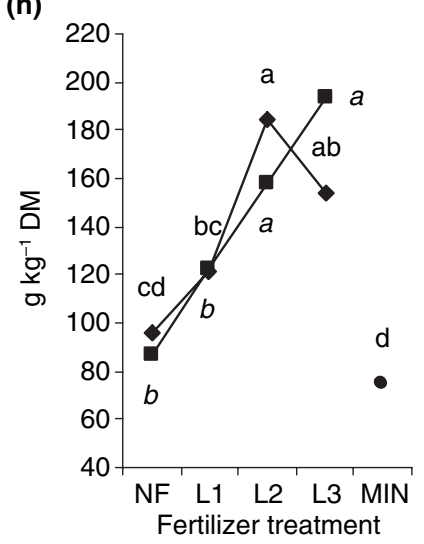

(c)

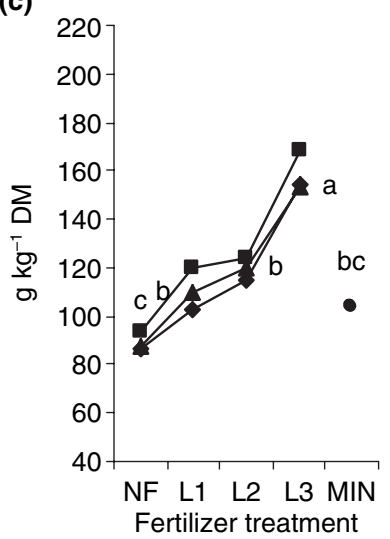

(f)

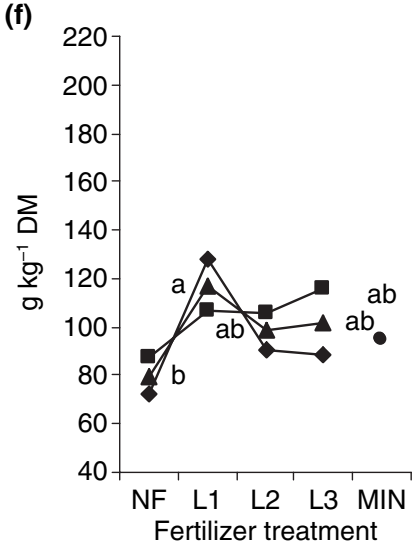

(i)

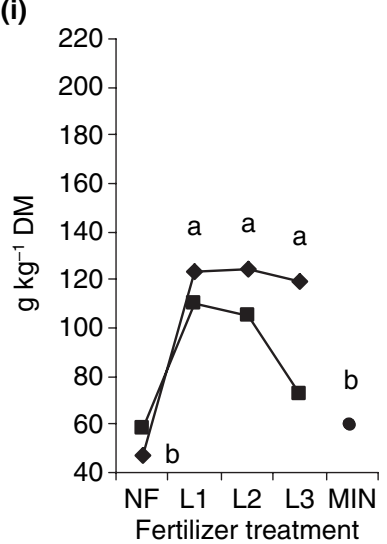

Figure 7 Mean crude protein (CP, $\left.\mathrm{g} \mathrm{kg}^{-1} \mathrm{DM}\right)$ concentrations in herbage under the different liming and fertilizer treatments in (a) 1998, (b) July 1998, (c) December 1998, (d) May 1999, (e) July 1999, (f) December 1999, (g) May 2000, (h) July 2000 and (i) December 2000. Liming application rate was $2.5 \mathrm{t} \mathrm{CO} \mathrm{Ca}_{3} \mathrm{ha}^{-1}$; NF, no-fertilizer treatment; LI, low sewage sludge application rate ( $160 \mathrm{~kg}$ total $\left.\mathrm{N} \mathrm{ha}^{-1}\right) ; \mathrm{L2}$, medium sewage sludge application rate $\left(320 \mathrm{~kg}\right.$ total $\left.\mathrm{N} \mathrm{ha}^{-1}\right)$; L3, high sewage sludge application rate (480 $\mathrm{kg}$ total $\mathrm{N} \mathrm{ha}^{-1}$ ); MIN, mineral fertilizer treatment. Different letters indicate significant differences between liming $(-\mathbf{\Lambda}-)$, fertilization treatments ( $\bullet$, no lime; $\mathbf{\square}$, lime) or the mean of both $(\mathbf{\Lambda})(P<0.05)$. 
(a)

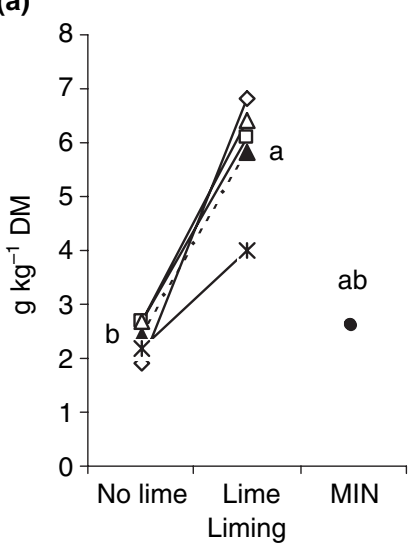

(d)

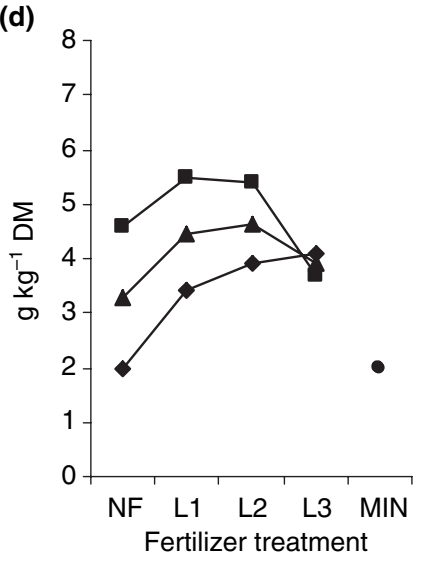

(g)

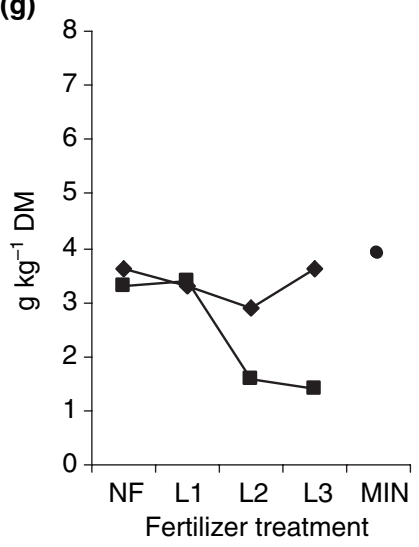

(b)

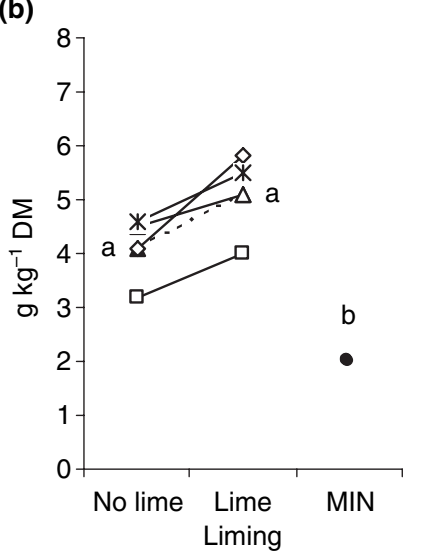

(e)

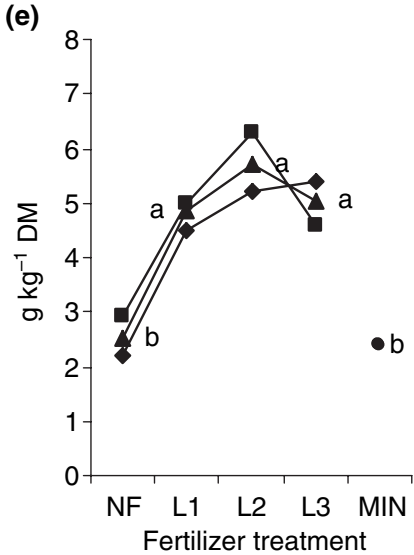

(h)

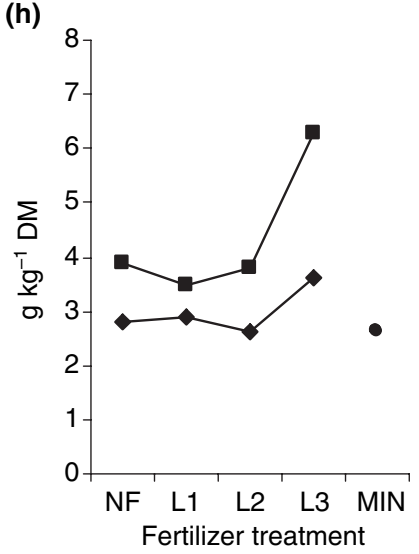

(c)

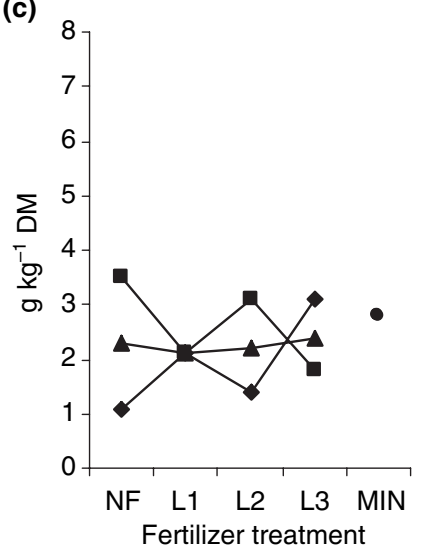

(f)

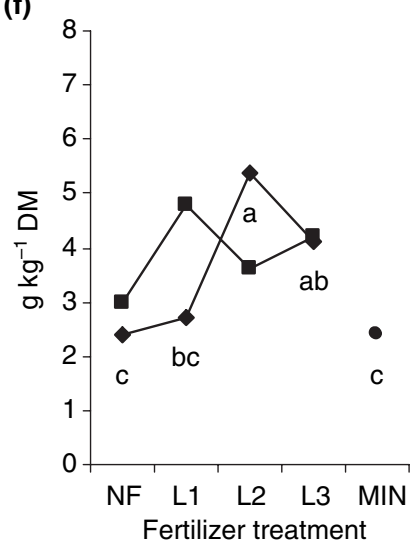

Figure 8 Mean Ca concentrations in herbage $\left(\mathrm{g} \mathrm{kg}^{-1} \mathrm{DM}\right)$ under the different liming and fertilizer treatments in (a) July 1998, (b) December 1998, (c) May 1999, (d) July 1999, (e) November 1999, (f) May 2000, (g) July 2000 and (h) November 2000. Liming application rate was $2.5 \mathrm{t} \mathrm{CO}_{3} \mathrm{Ca} \mathrm{ha}^{-1}$; NF, no-fertilizer treatment; $\mathrm{LI}$, low sewage sludge application rate ( $60 \mathrm{~kg}$ total $\left.\mathrm{N} \mathrm{ha}^{-1}\right) ; \mathrm{L} 2$, medium sewage sludge application rate $\left(320 \mathrm{~kg}\right.$ total $\left.\mathrm{N} \mathrm{ha}^{-1}\right) ; \mathrm{L}$, high sewage sludge application rate (480 kg total $\mathrm{N} \mathrm{ha}^{-1}$ ); MIN, mineral fertilizer treatment. Different letters indicate significantly differences between liming $\left(-\boldsymbol{\Lambda}-{ }^{-}\right)$, fertilization treatments $(\bullet$, no lime; $\mathbf{\square}$, lime) or the mean of both $(\mathbf{\Lambda})(P<0.05)$. 

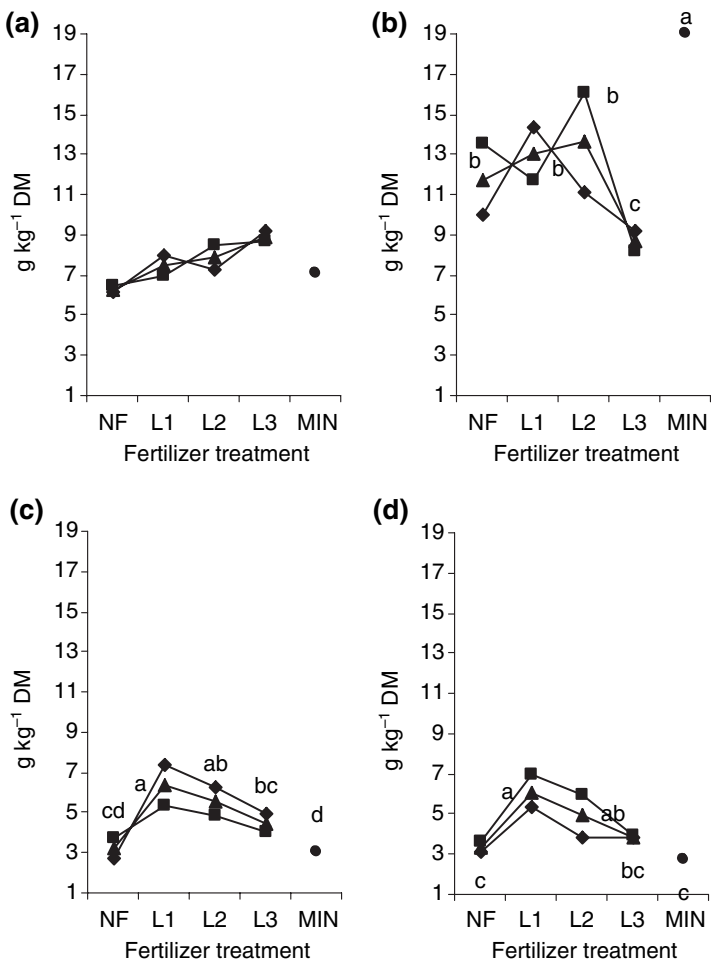

Figure 9 Mean $\mathrm{K}$ concentrations in herbage $\left(\mathrm{g} \mathrm{kg}^{-1} \mathrm{DM}\right)$ under the different liming and fertilizer treatments in (a) 1998, (b) May 1999, (c) November 1999 and (d) November 2000. Liming application rate was $2 \cdot 5 \mathrm{t} \mathrm{CO}_{3} \mathrm{Ca} \mathrm{ha}^{-1}$; NF, no-fertilizer treatment; LI, low sewage sludge application rate (I $60 \mathrm{~kg}$ total $\left.\mathrm{N} \mathrm{ha}^{-1}\right)$; L2, medium sewage sludge application rate (320 kg total $\mathrm{N} \mathrm{ha}^{-1}$ ); L3, high sewage sludge application rate (480 kg total $\mathrm{N} \mathrm{ha}^{-1}$ ); MIN, mineral fertilizer treatment. Different letters indicate significantly differences between fertilization treatments $(\mathbf{\Delta})(P<0.05)$.

followed by a marked reduction in $\mathrm{K}$ concentration in herbage in the summer.

There were no significant differences in $\mathrm{K}$ concentrations in herbage between the liming treatments. The $\mathrm{K}$ concentration in herbage was significantly affected by sewage sludge application rates for some harvests in 1999 and 2000. The low and medium sewage sludge application rates significantly increased K concentration in herbage in autumn 1999 and 2000. Mineral fertilization also increased $\mathrm{K}$ concentration in herbage with respect to the sewage sludge and no-fertilizer treatments in May $1999\left(19 \mathrm{~g} \mathrm{~kg}^{-1} \mathrm{DM}\right.$ with respect to $4.5 \mathrm{~g} \mathrm{~kg}^{-1} \mathrm{DM}$ in the no-fertilizer treatment) and in the first two harvests of $2000\left(8.9\right.$ and $9 \cdot 1 \mathrm{~g} \mathrm{~kg}^{-1} \mathrm{DM}$ in May and July, compared with 4.3 and $4.8 \mathrm{~g} \mathrm{~kg}^{-1} \mathrm{DM}$ with the no-fertilizer treatment).

Liming slightly increased the $\mathrm{Mg}$ concentrations in herbage only in the NF plots in July 1999 (Figure 10).
Throughout the experiment, all sewage sludge application treatments significantly modified the $\mathrm{Mg}$ concentrations in herbage. From 1999 onwards, the response of $\mathrm{Mg}$ concentrations in herbage to sewage sludge application depended significantly on whether or not liming had been applied. In general, application of sewage sludge resulted in increased $\mathrm{Mg}$ concentrations in herbage. The response in $\mathrm{Mg}$ concentrations in herbage was proportional to the sewage sludge application rate in non-limed plots in July $1999(\mathrm{Mg}=$ $\left.-1 \cdot 04 \mathrm{~N}^{2}+0 \cdot 73 \mathrm{~N}+0 \cdot 09, r^{2}=0 \cdot 99\right)$, in limed plots in November $1999\left(\mathrm{Mg}=-0 \cdot 75 \mathrm{~N}^{2}+0 \cdot 55 \mathrm{~N}+0 \cdot 11, r^{2}=\right.$ $0 \cdot 98)$ and in all plots in July $\left(\mathrm{Mg}=0 \cdot 23 \mathrm{~N}+0 \cdot 11, r^{2}=\right.$ $0 \cdot 74$ in limed plots and $\mathrm{Mg}=0 \cdot 18 \mathrm{~N}+0 \cdot 16, r^{2}=0.86$ in limed plots) and November 2000 in limed plots $(\mathrm{Mg}=$ $\left.0 \cdot 15 \mathrm{~N}+0 \cdot 10, r^{2}=0 \cdot 94\right)$. Mineral fertilizer had similar effects on $\mathrm{Mg}$ concentration to the no-fertilizer treatment, and in some cases smaller effects than obtained with the sewage sludge treatments.

\section{Discussion}

Total annual precipitation in 1999 and 2000 was relatively high compared with the 20 -year mean value. Total precipitation in summer 1999 (318 mm) and autumn 2000 (816 mm) were also higher than the mean values. Periods of drought, likely to have affected herbage production, occurred in June and August of 1998 and 2000, and in July 1999. Periods with low mean temperatures $\left(<6^{\circ} \mathrm{C}\right)$, which would limit pasture growth (Mosquera-Losada et al., 1999), occurred in January of the 3 years and in December 1998.

\section{Mineral contents in soil}

Adequate contents of ammonium and nitrate in soil are usually considered to be between 25 and $50 \mathrm{mg}$ $\mathrm{N}-\mathrm{NH}_{4}^{+} \mathrm{kg}^{-1}$ and 15 and $25 \mathrm{mg} \mathrm{N}-\mathrm{NO}_{3}^{-} \mathrm{kg}^{-1}$, depending on crop type (Whitehead, 1995). The soil studied here had high ammonium content (79.7-219.2 mg $\mathrm{N}-\mathrm{NH}_{4}{ }^{+} \mathrm{kg}^{-1}$ in 1998) and very low nitrate content (2.5-14.5 mg N-NO $\mathrm{Ng}_{3}^{-} \mathrm{kg}^{-1}$ ). The proportion of the two nitrogen forms found may be attributable to the very low activity of nitrifying bacteria populations present in strongly acid soils (Whitehead, 1995). This may also explain why ammonium levels in soil did not respond to liming, as the optimum $\mathrm{pH}$ for nitrifying bacteria is close to 6.5 , and soil $\mathrm{pH}$ was very low (maximum 5 ) in the final year. In line with the higher concentrations of ammonium, compared with nitrate, in sewage sludge, sewage sludge application increased the ammonium content in soil, as reported previously (Iwatsubo and Nagayama, 1994). However, in soils with a higher $\mathrm{pH}$ than in the present study, López-Díaz et al. (1999) did not observe any change in ammonium content in the 
(a)

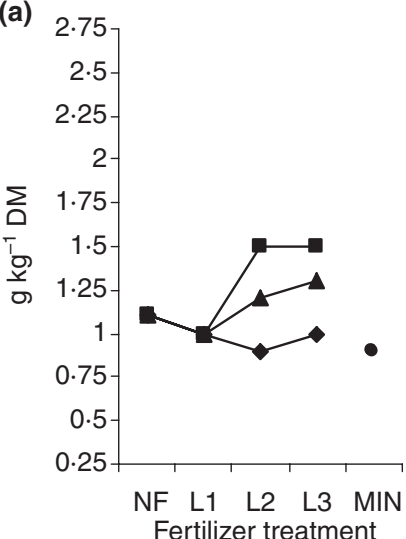

(d)

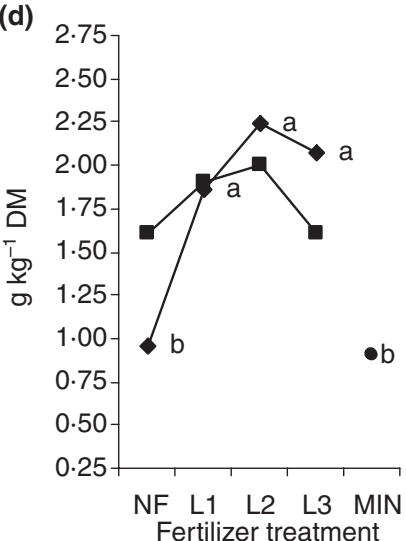

(g)

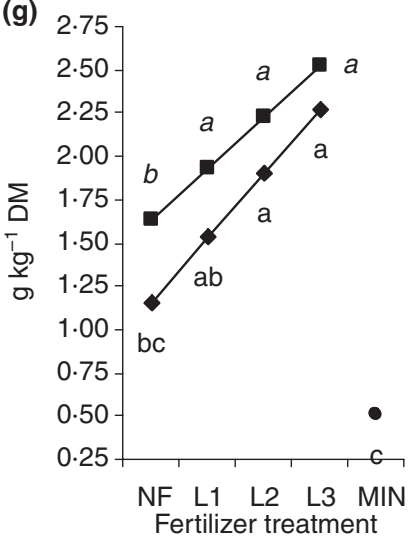

(b)

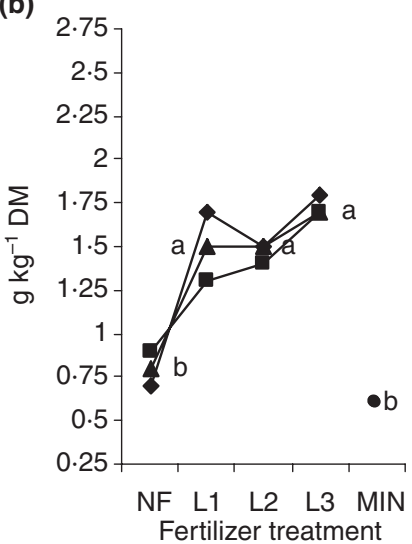

(e)

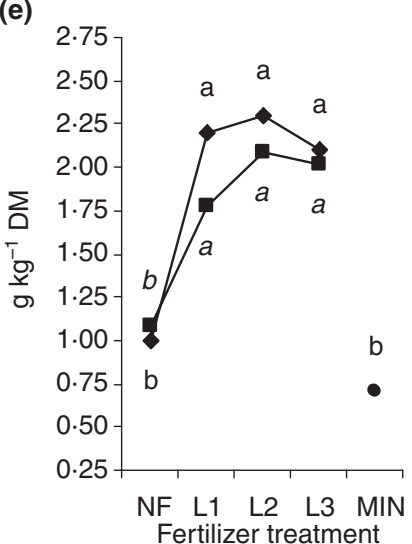

(h)

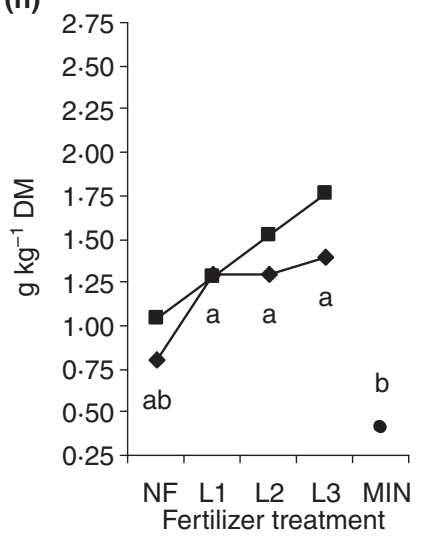

(c)

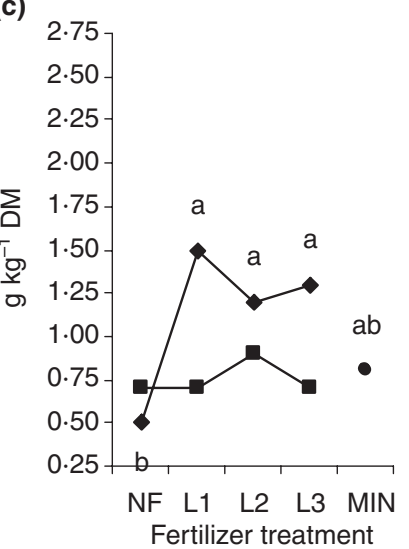

(f)

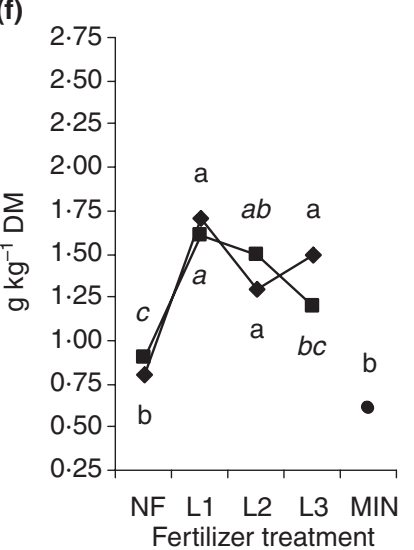

Figure 10 Mean $\mathrm{Mg}$ concentrations in herbage $\left(\mathrm{g} \mathrm{kg}^{-1} \mathrm{DM}\right)$ under the different liming and fertilization treatments in (a) July 1998, (b) December 1998, (c) May 1999, (d) July 1999, (e) November 1999, (f) May 2000, (g) July 2000 and (h) November 2000. Liming application rate was $2.5 \mathrm{t} \mathrm{CO}_{3} \mathrm{Ca}_{\mathrm{ha}}{ }^{-1}$; NF, no-fertilizer treatment; $\mathrm{LI}$, low sewage sludge application rate ( $60 \mathrm{~kg}$ total $\left.\mathrm{N} \mathrm{ha}^{-1}\right)$; L2, medium sewage sludge application rate $\left(320 \mathrm{~kg}\right.$ total $\left.\mathrm{N} \mathrm{ha}^{-1}\right)$; L3, high sewage sludge application rate (480 $\mathrm{kg}$ total $\mathrm{N} \mathrm{ha}^{-1}$ ); MIN, mineral fertilizer treatment different letters indicate significantly differences between fertilization treatments $(\checkmark$, no lime; $\mathbf{\square}$ lime) or the mean of both $(\mathbf{\Lambda})(P<0.05)$. 
soil after sewage sludge application, probably because of the better nitrification conditions (higher $\mathrm{pH}$ ) and the higher initial ammonium content in the soil (381$\left.465 \mathrm{mg} \mathrm{N}-\mathrm{NH}_{4}{ }^{+} \mathrm{kg}^{-1}\right)$. Increases in nitrate content after sewage sludge application have been reported for basic soils (Smith, 1996) and also for less acid soils than in the present experiment (Mosquera-Losada et al., 2002b).

The effect of organic fertilizers, such as sewage sludge, on soil mineral nitrogen forms usually varies between sampling dates, due to the complexity of the soil nitrogen cycle after application. The nitrogen cycle is more complex with organic fertilizers because mineral nitrogen availability depends on mineralization rate (Environmental Protection Agency, 1994), which is influenced by temperature and precipitation, and soil nitrate retention capacity, which is usually very low (Whitehead, 1995). This may explain why an effect of sewage sludge on nitrogen forms was not detected on some sampling dates.

The mineral fertilizer and unfertilized (control) treatments had similar effects on mineral $\mathrm{N}$ content in the soil. The amount of ammonium applied with the mineral fertilizer was much lower than that already present in the soil, so that the response in ammonium content in the soil was relatively minor, while the nitrate applied in the mineral fertilizer was either quickly taken up by plants or leached.

Before the experiment, the exchangeable Ca content $\left[1 \cdot 24 \mathrm{cmol}(+) \mathrm{kg}^{-1}\right]$ was lower than the threshold of $1.5 \mathrm{cmol}(+) \mathrm{kg}^{-1}$ considered to indicate a Ca deficiency in herbage (Buol et al., 1981). However, this level was within the range of $\left[0.37-2.60 \mathrm{cmol}(+) \mathrm{kg}^{-1}\right]$ reported by Calvo de Anta et al. (1992) for uncultivated soils in Galicia. The observed increase in exchangeable $\mathrm{Ca}$ content during the experiment could be explained by pasture establishment, as noted by Calvo de Anta et al. (1992) in acid soils. Exchangeable $\mathrm{K}$ [0.15$0.30 \mathrm{cmol}(+) \mathrm{kg}^{-1}$ ] and $\mathrm{Mg}$ contents were similar to those observed by Calvo de Anta et al. (1992) in uncultivated Galician soils, and at the start of the experiment they were, in several cases, lower than the thresholds of $0 \cdot 2 \mathrm{cmol}(+) \mathrm{K} \mathrm{kg}^{-1}$ and $0 \cdot 4 \mathrm{cmol}(+) \mathrm{Mg} \mathrm{kg}^{-1}$ considered to indicate deficiencies of these elements (Buol et al., 1981). This could also explain the low proportion of legumes seen in this experiment (Rigueiro-Rodríguez et al., 2005).

Lime and sewage sludge applications increased the exchangeable $\mathrm{Ca}$ and $\mathrm{Mg}$ contents in soil. This is, in part, directly attributable to the $\mathrm{Ca}$ and $\mathrm{Mg}$ concentrations of the lime and sewage sludge. In addition, both of these treatments increased $\mathrm{pH}$ and reduced $\mathrm{Al} / \mathrm{IC}$, leading to its replacement by basic cations (Smith, 1996; Mälkönen et al., 1999). However, some previous studies have found that sewage sludge application reduces $\mathrm{Mg}$ availability when soil $\mathrm{pH}$ or $\mathrm{Ca}$ inputs are high, since Ca can act as an antagonist of $\mathrm{Mg}$ in the soil (O'Riordan et al., 1987; Vivekanandan et al., 1991).

The increase in available Ca content in the soil after the application of sewage sludge was obtained later than after liming, in line with the lower initial Ca input provided by the sewage sludge. An increase in the available Ca content after sewage sludge application to soil has been observed by Vivekanandan et al. (1991). In most cases, the response in available $\mathrm{Mg}$ content in the soil was proportional to the amount of $\mathrm{N}$ applied with the sewage sludge, as observed by MosqueraLosada et al. (2002a); this is probably due to aluminium precipitation, which overcomes the $\mathrm{Ca} / \mathrm{Mg}$ antagonism.

Exchangeable $\mathrm{K}$ content in the soil was reduced by liming. This could be explained by a strong antagonism in the soil between $\mathrm{K}$ and $\mathrm{Ca}$, with $\mathrm{K}$ being leached (Barber, 1995). However, the response in exchangeable $\mathrm{K}$ content to sewage sludge application depends on the herbage production. For example, in autumn 1999, the reduction in exchangeable $\mathrm{K}$ content when sewage sludge was applied, with respect to the mineral fertilizer and no-fertilizer treatments, could be explained by the increased pasture production in the sludge-treated plots during the spring, which probably caused a dilution effect. In this case, the increase in available $\mathrm{K}$ content was inversely proportional to the rate of sewage sludge application, with the response to the highest dose (L3) being similar to that of the no-fertilizer treatment. After three annual applications, sewage sludge increased the available K content, as observed by Vivekanandan et al. (1991). The delay in the response to the sewage sludge treatments is attributable to the low proportion of $\mathrm{K}$ in the sludge.

Mineral fertilizer increased the exchangeable K content in the summer and autumn of 2000, which is directly attributable to its $\mathrm{K}$ contribution $\left(240 \mathrm{~kg} \mathrm{~K}_{2} \mathrm{O}\right.$ after 3 years). However, the lack of response in exchangeable $\mathrm{Mg}$ content in the soil to mineral fertilizer could be explained because this fertilizer has no $\mathrm{Mg}$ and reduces soil pH (Mohebbi and Mahler, 1988).

\section{Mineral concentrations in herbage}

The increase in soil $\mathrm{N}$ content (both ammonium and nitrate) obtained after sewage sludge application led to an increase in CP concentrations in herbage. Crude protein concentrations obtained after sewage sludge application were similar to those reported in previous studies in temperate regions (90-250 $\mathrm{g} \mathrm{kg}^{-1}$ DM; Mosquera-Losada et al., 2004). Similarly, the lower CP concentrations in herbage on the unfertilized control and mineral fertilizer treatments are in line with previous studies $\left(40-160 \mathrm{~g} \mathrm{~kg}^{-1}\right.$; Mosquera-Losada et al., 2002b), and are attributable to differences in the 
botanical composition of the pasture. There was a higher proportion of unsown species (e.g. Agrostis curtisii, Agrostis duriaei, Pseudoarrhenatherum longifolium, Holcus mollis) present in the unfertilized and mineralfertilized pasture (Rigueiro-Rodríguez et al., 2005), and these species generally have lower CP concentrations than sown pasture species (Whitehead, 1995). By contrast, the higher $\mathrm{N}$ availability in the sewage sludge-fertilized plots may have favoured the growth of protein-rich sown species (Mosquera-Losada et al., $2001 b)$. The low CP concentrations in forage after the application of mineral fertilizer in the present study are attributable to the low abundance of clover in the pastures, which is attributed to the low soil $\mathrm{pH}$.

Maximum CP concentrations and treatment differences were seen in spring and are in line with the more marked differences in soil nitrate content and the better growing conditions. A second increase in CP concentration in forage was seen in the autumn in the first year of the study; such an increase is normal for lowland pastures in Galicia (Mosquera-Losada et al., 2004), but it was not detected in the second and third year, probably due to the lower temperatures, which limited herbage growth in these periods and, therefore, limited the responses to the different treatments.

The minimum dietary concentrations of CP for maintenance of live weight in goats $\left(60 \mathrm{~g} \mathrm{~kg}^{-1} \mathrm{DM}\right)$ (Lamand, 1981), horses (85 $\mathrm{g} \mathrm{kg}^{-1} \mathrm{DM}$ ) (NRC, 1989) and cattle (100 $\left.\mathrm{g} \mathrm{kg}^{-1} \mathrm{DM}\right)$ (NRC, 2000) were, in some cases, below those reported in the herbage on some of the fertilizer treatments.

Calcium concentrations in herbage were similar to those reported by García et al. (1986a) after lime application and by Mosquera-Losada et al. (2002b) in forest soils, but lower than those reported by MosqueraLosada et al. (2004) in agricultural soils after application of mineral fertilizer. In all cases, the values were within the lower part of the normal range established by Grace (1983a) for temperate pastures. Concentrations of $\mathrm{K}$ in herbage (1·3-19 $\left.\mathrm{g} \mathrm{kg}^{-1} \mathrm{DM}\right)$ were similar to or lower than the range of values reported by Whitehead (1995) (15-30 $\mathrm{g} \mathrm{kg}^{-1} \mathrm{DM}$ ) for $L$. perenne and T. repens, but lower than those reported by Mosquera-Losada et al. (2004) $\left(11 \cdot 2-26.4 \mathrm{~g} \mathrm{~kg}^{-1} \mathrm{DM}\right)$ for the same species in agricultural soils. Finally, Mg concentrations (0.4$\left.2.5 \mathrm{~g} \mathrm{~kg}^{-1} \mathrm{DM}\right)$ in herbage were within the normal ranges reported by Grace (1983b) (1.0-3.4 $\left.\mathrm{g} \mathrm{kg}^{-1} \mathrm{DM}\right)$, by García et al. (1986b) $\left(0 \cdot 2-2 \cdot 6 \mathrm{~g} \mathrm{~kg}^{-1} \mathrm{DM}\right)$ for Galician forest soils, and by Mosquera-Losada et al. (2004) (1·7$\left.2 \cdot 9 \mathrm{~g} \mathrm{~kg}^{-1} \mathrm{DM}\right)$ for Galician agricultural soils in which L. perenne and $T$. repens had been sown.

Seasonal variations in $\mathrm{Ca}, \mathrm{K}$ and $\mathrm{Mg}$ concentrations in herbage depend on the effects of temperature and precipitation on herbage production at each harvest and on the length of the grazing period. Wilman et al.
(1994) reported that the Ca concentration in herbage has maximum values in spring and autumn. In the present study, however, there were no seasonal variations in the concentrations in herbage for these elements. This may have been because of the recent establishment of the pasture and weather conditions over the study period (with warm summer temperatures and high precipitation, especially in 2000), which may have favoured leaching of these elements, and extension of the pasture growth period in late spring and early summer. Trees may create a microclimate that buffers seasonality (Mosquera-Losada et al., 2001b). In 1998 and 2000, Mg concentrations were usually stable throughout the year. In spring and summer in 1999, Ca, $\mathrm{K}$ and $\mathrm{Mg}$ concentrations in herbage were low probably because of high herbage production and a consequent dilution effect.

In 1998 and autumn 2000, Ca concentration in herbage was increased by liming, as a direct result of the Ca content of the lime. However, liming did not significantly increase the $\mathrm{Mg}$ concentration in forage, despite a similar response to treatments in terms of plant species composition and available $\mathrm{Mg}$ content in the soil. This could be explained by $\mathrm{Ca} / \mathrm{Mg}$ antagonism at the plant level (Barber, 1995). Concentration of $\mathrm{K}$ in herbage did not vary with liming, as observed by Stevens and Laughlin (1996).

Concentrations of $\mathrm{Ca}$ and $\mathrm{Mg}$ in herbage were increased by application of sewage sludge in some harvests, as reported by Tiffany et al. (2000) for $\mathrm{Mg}$ concentration in herbage in a very acid soil ( $\mathrm{pH} 4 \cdot 6)$. In autumn 1999 and 2000, sewage sludge application also increased $\mathrm{K}$ concentration in forage, as reported Tiffany et al. (2000). For all three elements ( $\mathrm{K}$, Ca and Mg), these increases in concentration were attributable both to direct input and to effects on availability. Moreover, the increase in $\mathrm{Mg}$ concentration in herbage is attributable to the higher proportion of sown species, like $D$. glomerata, L. perenne and T. repens, which have higher $\mathrm{Mg}$ concentrations than many unsown species (Whitehead, 1995; Rigueiro-Rodríguez et al., 2002). The response in $\mathrm{Mg}$ concentration in herbage was only proportional to the rate of application of sewage sludge on the last two sample dates, probably due to the cumulative effect of previous applications.

There were no significant between-treatment differences in $\mathrm{K}$ concentration in herbage except in the autumn of 1999 and 2000; this is attributable to the higher proportion of sown species, which generally have lower $\mathrm{K}$ concentrations than unsown species (Hopkins et al., 1994), when sewage sludge was applied. The normal ranges for $\mathrm{K}$ concentration in the herbage of L. perenne, T. repens and D. glomerata are $15-28 \mathrm{~g} \mathrm{~kg}^{-1}$ (Whitehead, 1995), 16-30 $\mathrm{g} \mathrm{kg}^{-1}$ (Whitehead, 1995) and $5-10 \mathrm{~g} \mathrm{~kg}^{-1}$ (Mosquera-Losada et al., 200 lb), 
respectively. Moreover, a dilution effect was produced by the higher herbage production under applications of sewage sludge.

In some harvests, application of mineral fertilizer increased $\mathrm{K}$ concentrations in herbage, as found by Babnik et al. (1996). This could be explained by the high $\mathrm{K}$ content of this fertilizer, which did not lead to an increase in herbage production. However, Mg concentrations obtained after the application of mineral fertilizer were sometimes lower than after the application of sewage sludge. This is attributable to the fact that the soil had low Mg content and the mineral fertilizer did not contain $\mathrm{Mg}$, and this may have further increased soil acidity.

In general, $\mathrm{Ca}$ and $\mathrm{K}$ concentrations in herbage were similar to or higher than those considered necessary for maintenance of live weight in cattle $\left(1.8\right.$ and $60 \mathrm{~g} \mathrm{~kg}^{-1}$ DM, respectively) and sheep $\left(2 \cdot 1\right.$ and $\left.5 \cdot 0 \mathrm{~g} \mathrm{~kg}^{-1} \mathrm{DM}\right)$ (NRC, 1985), but minimum $\mathrm{Mg}$ concentration in herbage were not met in either case $\left(1.8 \mathrm{~g} \mathrm{~kg}^{-1}\right.$ for cattle, $0.8 \mathrm{~g} \mathrm{~kg}^{-1}$ for sheep) (NRC, 1985, 2000).

The concentration of $\mathrm{K}$ in all herbages met the requirements for maintenance of live weight in horses $\left(4.0 \mathrm{~g} \mathrm{~kg}^{-1} \mathrm{DM}\right)$ and goats $\left(5.0 \mathrm{~g} \mathrm{~kg}^{-1} \mathrm{DM}\right)$. The concentration of $\mathrm{Ca}$ in herbage from pasture that had received lime or sewage sludge also met the requirements for maintenance of live weight in horses $\left(3.0 \mathrm{~g} \mathrm{~kg}^{-1} \mathrm{DM}\right)$ and goats $\left(3.4 \mathrm{~g} \mathrm{~kg}^{-1} \mathrm{DM}\right)$. The concentration of $\mathrm{Mg}$ in herbage from pasture that had received mineral fertilizer or no-fertilizer treatments did not reach the minimum requirements for maintenance of live weight in sheep $\left(0.8 \mathrm{~g} \mathrm{~kg}^{-1}\right)$ or horses $\left(0.9 \mathrm{~g} \mathrm{~kg}^{-1}\right)$ (Lamand, 1981; NRC, 1989).

\section{Conclusions}

The results indicate that the responses in ammonium and nitrate content in soil to liming and sewage sludge application reflected the initial soil $\mathrm{pH}$. Transformation from ammonium to nitrate is limited, so that added ammonium tends to be accumulated when added to acid soils. However, in soils with a higher $\mathrm{pH}$ there is no such accumulation and nitrate levels are increased. In acid and less acid soils, nitrate content in the soil is increased by sewage sludge application. Liming and sewage sludge application increase the available $\mathrm{Ca}$, $\mathrm{Mg}$, this effect coming earlier after liming, and $\mathrm{K}$ (only sewage sludge) content in soil. This can be explained by the direct input of these components, and by the modification of $\mathrm{pH}$ that they cause. However, the strong antagonism between $\mathrm{K}$ and $\mathrm{Ca}$ in the soil reduced the available $\mathrm{K}$ content of the soil after liming.

The low availabilities in the soil of the different elements evaluated and the development of unsown species generally led to low concentrations of these elements in the herbage. Liming and sewage sludge application increased the concentration of these elements in forage, although the responses were not the same in the 3 years evaluated, but rather depended on interactions between weather conditions and pasture composition, and production, and the antagonism in the plant between some cations. The positive effects on nutrient availability arising from liming and sewage sludge caused a positive effect on herbage production (at higher application rates of sewage sludge and with liming treatments) and on tree growth (with liming and at low application rates of sewage sludge) (MosqueraLosada et al., 2001a).

\section{References}

Babnik D., Znidarsic-Pongrac V., Verbic J. and Verbic J. (1996) The effect of fertilization on the concentration of mineral elements in grasses, forbs and legumes from the permanent karst grassland. Grassland Science in Europe, $\mathbf{1}$, 373-376.

Bailey J.S. (1995) Liming and nitrogen efficiency: some effects of increased calcium supply and increased soil $\mathrm{pH}$ on nitrogen recovery by perennial ryegrass.

Communications in Soil Science and Plant Analysis, 26, $1233-$ 1246.

Barber S.A. (1995) Soil nutrient bioavailability: a mechanistic approach, 2nd edn. New York, USA: John Wiley \& Sons.

BOE (1990) Real Decreto 1310/1990 del 29 octubre 1990, que regula la utilización de los lodos de depuración. [Decree 1310/ 1990 of 29th October 1990 that regulates the use of sewage sludge]. Madrid, Spain: Ministerio Agricultura, Pesca y Alimentación.

Bremner M. (1965) Nitrogen availability indexes. In: Black C.A. (ed.) Methods of soil analysis, Part 2, pp. 1324-1345. Madison, WI: American Society of Agronomy.

Brodersen J., Juul J. and Jacobsen H. (2002) Review of selected waste streams: sewage sludge, construction and demolition waste, waste oils, waste from coal-fired power plants and biodegradable municipal waste. EEA Technical Report 69. Copenhagen, Denmark: European Environment Agency.

Buol S.W., Hole F.D. and McCracken R.J. (1981) Génesis y clasificación de suelos. [Genesis and classification of soils]. Mexico City, Mexico: Trillas.

Calvo de Anta R., Macías F. and Riveiro Cruz A. (1992) Aptitud agronómica de la provincia de La Coruña (cultivos, pino, roble, eucalipto y castaño). [Agronomic suitability of $\mathrm{La}$ Coruña province (crop, pine, oat, eucalytus and chestnut)]. Santiago de Compostelo, Spain: Dpto. de Edafología y Química Agrícola, Facultad de Biología, University of Santiago de Compostela.

Castro P., González A. and Prada D. (1990) Determinación simultánea de nitrógeno y fósforo en muestras de pradera. (Simultaneous determination of nitrogen and phosphorus in pasture samples.) XXX Reunión Científica de la Sociedad Española para el Estudio de los Pastos, Spain, 1990, pp. 200-207. 
Chambers B.J. and Garwood T.W.D. (1998) Lime loss rates from arable and grassland soils. Journal of Agricultural Science, Cambridge, 131, 455-464.

European Commission (1986) Council Directive of 12 June 1986 on the protection of the environment and, in particular of the soil, when sewage sludge is used in agriculture (86/278/EEC). EC Official Journal L 181 04/07/ 1986. Brussels, Belgium: European Commission.

European Commission (1991) Council Directive of 21 May 1991 concerning urban waste water treatment (91/271/ EEC). EC Official Journal L 135 30/05/1991. Brussels, Belgium: European Commission.

Environmental Protection Agency (1994) Land application of sewage sludge. A guide for land appliers on the requirements of the federal standards for the use and disposal of sewage sludge, 40 CFR Part 503. Washington, DC: Environment Protection Agency.

García P., Mombiela F.A. and Mosquera A. (1986a) Efectos del encalado sobre la composición química de praderas establecidas en terrenos a monte. I. Calcio y Fósforo. (Effects of lime on the chemical composition of pastures established on forest soils. I. Ca and P). Investigación Agraria: Producción y Sanidada Animal, 1, 135-145.

García P., Mombiela F.A. and Mosquera A. (1986b) Efectos del encalado sobre la composición química de praderas establecidas en terrenos a monte. II. $\mathrm{Mg}, \mathrm{Na}, \mathrm{K}, \mathrm{Al}$ y $\mathrm{Cu}$. [Effects of lime on the chemical composition of pastures established on forest soils. II. $\mathrm{Mg}, \mathrm{Na}, \mathrm{K}, \mathrm{Al}$ and $\mathrm{Cu}$ ]. Investigación Agraria: Producción y Sanidad Animal, $\mathbf{1}$, $147-158$

Grace N.D. (1983a) Calcium. In: Grace N.D. (ed). The mineral requirements of grazing ruminants. New Zealand Society of Animal Production, Occasional Publication. 9, 100-105. Christchurch, New Zealand: New Zealand Society of Animal Production.

Grace N.D. (1983b) Magnesium. In: Grace N.D. (ed). The mineral requirements of grazing ruminants. New Zealand Society of Animal Production, Occasional publication. 9, 92-99. Christchurch, New Zealand: New Zealand Society of Animal Production.

Guitián F. and Carballas T. (1976) Técnicas de análisis de suelos (Methods of Soil Analyses). Santiago de Compostela, Spain: Pico Sacro.

Hopkins A., Adamson A.H. and Bowling P.J. (1994) Response of permanent and reseeded grassland to fertilizer nitrogen. 2. Effects on concentrations of $\mathrm{Ca}, \mathrm{Mg}$, $\mathrm{K}, \mathrm{Na}, \mathrm{S}, \mathrm{P}, \mathrm{Mn}, \mathrm{Zn}, \mathrm{Cu}, \mathrm{Co}$ and $\mathrm{Mo}$ in herbage at a range of sites. Grass and Forage Science, 49, 9-20.

Iwatsubo G. and Nagayama Y. (1994) Effects of sewagewater spraying on mineral cycling in a forest ecosystem. Forest Ecology and Management, 68, 75-85.

Lamand M. (1981) Metabolisme et bésoins en oligoelements des chèvres. (Metabolism and requirements of oligoelements in goats). Proceedings of International Conference of Nutrition and Feeding Systems, Tours, France, 1981.

López-Díaz M.L., Mosquera-Losada M.R. and RigueiroRodríguez A. (1999) Nitrogen mineralization from different sewage sludge doses in grasslands. Proceedings of
European Grassland Federation 10th Nitrogen Workshop, Copenhagen, Denmark, 1999, pp. 1-4.

López-Díaz M.L., Mosquera-Losada M.R. and RigueiroRodríguez A. (2005) Tree growth and pasture production under sewage sludge fertilization. In: Mosquera-Losada M.R., Rigueiro-Rodríguez A. and McAdam J. (eds) Silvopastoralism and Sustainable Land Management, pp. 154-156. Wallingford, UK: CABI Publishing.

Mälkönen E., Derome J., Fritze H., Helmisaari H.S., Kukkola M., Kytö M., Saarsalmi A. and Salemaa M. (1999) Compensatory fertilization of Scots pine stands polluted by heavy metals. Nutrient Cycling in Agroecosystems, 55, 239-268.

Mohebbi S. and Mahler R.L. (1988) The effect of soil pH manipulation on chemical properties of an agricultural soil from Northern Idaho. Commununications in Soil Science and Plant Analysis, 19, 1795-1812.

Mosquera-Losada M.R., González-Rodríguez A. and Rigueiro-Rodríguez A. (1999) Ecología y manejo de praderas. (Ecology and management of pastures). Madrid, Spain: Ministerio de Agricultura, Pesca y Alimentación.

Mosquera-Losada M.R., Rigueiro-Rodríguez A. and LópezDíaz M.L. (200la) Sewage sludge fertilization of a silvopastoral system with pines in north-western Spain. Agroforestry Systems, 53, 1-10.

Mosquera-Losada M.R., Rigueiro-Rodríguez A., López-Díaz M.L. and Rodríguez-Barreira S. (200lb) Efecto del sombreado y la época de siembra en el establecimiento y producción de varias especies pratenses. (Effect of shade and sowing time in the establishment and production of some pasture species). Investigación Agraria, 16, 169-186.

Mosquera-Losada M.R., Rigueiro-Rodríguez A. and Villarino-Urtiaga J.J. (2001c) Establecemento de sistemas silvopastorais. (Establishment of silvopastoral systems). Galicia, Spain: Consellería de agricultura, Gandería e Política Agroalimentaria, Xunta de Galicia.

Mosquera-Losada M.R., Rigueiro-Rodríguez A. and LópezLópez M.J. (2002a) Organic fertilization on highland pastures. FAO REU Technical Series 64, pp. 53-56. Rome, Italy: FAO.

Mosquera-Losada M.R., López-Díaz M.L., Iglesias-Rego R., Fernández-Núñez E., Fernández-Gómez S., JardónBouzas B. and Rigueiro-Rodríguez A. (2002b) Micronutrient content of main natural herbs, shrubs and forage trees in NW Spain. Grassland Science in Europe, 7, 88-89.

Mosquera-Losada M.R., González-Rodríguez A. and Rigueiro-Rodríguez A. (2004) Fertilization with nitrogen and potassium on pastures in temperate areas. Journal of Range Management, 57, 280-290.

NRC (1985) Nutrient requirements of sheep. Washington, DC: National Academic Press.

NRC (1989) Nutrient requirements of horses. Washington, DC: National Academic Press.

NRC (2000) Nutrient requirements of beef cattle. Washington, DC: National Academic Press.

O’Riordan E.G., Dodd V.A., Fleming G.A. and Tunney H. (1987) The fertilizer nutrient value of an anaerobically digested sewage sludge under grassland field conditions. 
Irish Journal of Agricultural and Food Research, 26, 199-211.

Rigueiro-Rodríguez A., López-Díaz M.L., Iglesias-Rego R., Fernández-Núñez E., Fernández-Gómez S., JardónBouzas B. and Mosquera-Losada M.R. (2002) Macronutrient content of main natural herbs, shrubs and forage trees in NW Spain. Grassland Science in Europe, 7, 90-91.

Rigueiro-Rodríguez A., López-Díaz M.L. and MosqueraLosada M.R. (2005) Effect of liming and sewage sludge application on the botanical composition of a pasture grown under Pinus radiata. Grassland Science in Europe, 10, 652-655.

SAS (2001) User's Guide: Statistics. Cary, NC: SAS Institute Inc.

Sinclair F., Eason B. and Hooker J. (2000) Understanding and management of interactions. In: Hislop M. and Claridge J. (eds) Agroforestry in the UK. Forestry Commission Bulletin 122, pp. 17-30. Edinburgh, UK: Forestry Commission.

Smith S.R. (1996) Agricultural recycling of sewage sludge and the environment. Wallingford, UK: CABI Publishing.

Stevens R.J. and Laughlin R.J. (1996) Effects of lime and nitrogen fertilizer on two sward types over a 10-year period. Journal of Agricultural Science, Cambridge, 127, 451-461.
Tiffany M.E., McDowell L.R., O'Connor G.A., Nguyen H., Martin F.G., Wilkinson N.S. and Cardoso E.C. (2000) Effects of pasture-applied biosolids on forage and soil concentrations over a grazing season in North Florida. I. Macrominerals, crude protein and in vitro digestibility. Communications in Soil Science and Plant Analysis, 31, 201213.

Varian (1989) Analytical methods. Mulgrave, Victoria, Australia: Varian Inc.

Vivekanandan M., Brown J.R., Williams J., Clevenger T., Belyea R. and Tumbleson M.E. (1991) Tolerance of forage legumes to lime-stabilized sludge. Communications in Soil Science and Plant Analysis, 22, 449-463.

Wheeler D.M. (1998) Investigation into the mechanisms causing lime responses in a grass/clover pasture on a clay loam soil. New Zealand Journal of Agricultural Research, 41, 497-515.

Whitehead D.C. (1995) Grassland nitrogen. Wallingford, UK: CABI Publishing.

Wilman D., Acuña P.G.H. and Michaud P.J. (1994) Concentrations of $\mathrm{N}, \mathrm{P}, \mathrm{K}, \mathrm{Ca}, \mathrm{Mg}$ and $\mathrm{Na}$ in perennial ryegrass and white clover leaves of different ages. Grass and Forage Science, 49, 422-428. 